\title{
An Assessment of Groundwater Recharge at a Regional Scale for Sustainable Resource Management: Province of Alicante (SE Spain)
}

\author{
Miguel Fernández-Mejuto ${ }^{1,2, *}$, José Miguel Andreu ${ }^{2}$, Ernesto García-Sánchez ${ }^{3}$ and Rebeca Palencia $^{1}$ \\ 1 Área de Ciclo Hídrico, Diputación Provincial de Alicante, 03006 Alicante, Spain; \\ r.palencia@diputaciondealicante.es \\ 2 Institute of Water and Environmental Sciences, University of Alicante, 03690 Alicante, Spain; \\ andreu.rodes@ua.es \\ 3 Department of Agrochemistry and Environment, University Miguel Hernández Elche, 03202 Elche, Spain; \\ ernesto.garcia@umh.es \\ * Correspondence: mfmejuto@diputaciondealicante.es
}

Citation: Fernández-Mejuto, M.; Andreu, J.M.; García-Sánchez, E.; Palencia, R. An Assessment of Groundwater Recharge at a Regional Scale for Sustainable Resource Management: Province of Alicante (SE Spain). Water 2021, 13, 862. https://doi.org/10.3390/w13060862

Academic Editor: Joaquin Melgarejo

Received: 13 January 2021

Accepted: 9 March 2021

Published: 22 March 2021

Publisher's Note: MDPI stays neutral with regard to jurisdictional claims in published maps and institutional affiliations.

Copyright: (C) 2021 by the authors. Licensee MDPI, Basel, Switzerland. This article is an open access article distributed under the terms and conditions of the Creative Commons Attribution (CC BY) license (https:/ / creativecommons.org/licenses/by/ $4.0 /)$.

\begin{abstract}
For decades, the Province of Alicante, located in the Southeast of Spain, has experienced important economic development associated with groundwater exploitation. The scarcity of superficial resources and irregular distribution in the time and space of rainfall, typical of the Mediterranean environment, together with the extensive limestone outcrops, have made groundwater a key resource for the area. However, insufficient knowledge about aquifers, especially the lack of precise recharge estimates, hinders regional water management. This study establishes updated recharge estimates and water budgets for the 200 aquifers found in Alicante, using readily usable methodologies and available data. These are soil water budget models, groundwater flow models, water table fluctuation methods, and spring flow analyses. The results show low mean annual values of recharge from precipitation ( $69 \mathrm{~mm} /$ year and a coefficient of $12 \%$ ) and two main differentiated domains. The first one, in the northeast of the province, under more humid climatic conditions with larger carbonate aquifer systems, has higher recharge coefficients, ranging from $14 \%$ to $24 \%$, and greater resources. For the rest of the province, where aquifers are smaller and annual averages of rainfall range between 250 and $400 \mathrm{~mm}$, average recharge rates are low (9-12\%).
\end{abstract}

Keywords: aquifer management; groundwater recharge; Mediterranean region; recharge coefficient; Natural Aquifer Recharge (RENATA); Southeast Spain

\section{Introduction}

The search for new water resources to supply the demands of a growing global population has significantly increased during the last few decades [1,2]. Nowadays, $20 \%$ of the world's population is supplied with groundwater, and there are many countries whose principal economic activities are based on groundwater. In many cases, in arid and semiarid areas, groundwater is almost the only water resource available, and, paradoxically, many of these areas also show excellent conditions to develop prosperous water-dependent activities such as irrigated agriculture or tourism [3-8].

Alicante province, in southern Spain, is one of these regions where groundwater has been intensively used for more than sixty years. The bonanza of the climate, especially favorable for intensive agriculture, has allowed the transformation from traditional nonirrigated crops to high-productivity irrigated crops. This was linked to an important change in landscape due to the increase of cropland. This increase in agriculture began in the middle of the last century, and, from then on, large volumes of water for irrigation have been required. Simultaneously, the Alicante province has also experienced the emergence of tourism. As a coastal area with a benign climate, Alicante has become one of the main sun-and-beach destinations of Spain, which implies welcoming a high number of visitors, 
particularly during summer. Touristic activity implies an increment in urban water supply in the coastal areas, which, in some locations, doubles the usual demand.

Although Alicante is a region with scarce water resources, its location in the semiarid southeast peninsular, together with the lack of permanent rivers of importance, implies that water demands cannot be satisfied with surface water, so water supply requires groundwater exploitation. Over the years, the development of society has increased the pressure over natural resources, which has caused numerous problems of overexploitation on many subterranean reservoirs, with impacts such as significant decreases in piezometric levels, the drying up of springs, effects on surface watercourses linked to groundwaters, salinization of aquifers, and impacts on aquatic ecosystems [9-11]. However, overexploitation has also produced economic or social impacts, such as increasing costs of water elevation and disputes between users and water management public agencies [11].

In this context of intensive use of groundwater, some aquifers have been nearly exhausted, leading to their abandonment or to a substantial decrease in extractions. Part of this water has been substituted with alternative resources such as desalination, reutilization, or water transfers. At present, $11.4 \%$ of supply comes from desalination and $11.5 \%$ from reuse/regeneration [12-15]. Water transfers from other basins, especially for irrigation and urban supply in the southwest of the province, is another strategy followed to satisfy demand [16].

In this situation, where complete sustainability has not been reached and there is still aquifer overexploitation and unsatisfied agricultural demands, climate change might have a serious impact. Many climate models predict dramatic changes in different regions of the planet, among which are the Mediterranean areas. It is forecasted that an increase in temperature and a reduction in precipitation during the 21st century will affect southeast Spain [17-19]. These changes will surely affect groundwater, and, thus, it is necessary to improve the knowledge on aquifer budgets, especially on the recharge of aquifers, a variable that is going to be directly affected and critical for sustainability [20-23].

These challenges are common to (semi-)arid regions, where groundwater guarantees food and water supply even in drought periods, a key to social development and economic growth [24]. However, while groundwater reserves in arid areas may be high and have favored the increase of irrigation agriculture, recharge rates are low and sometimes negligible; thus, exploitation can lead to long-term water table depletion and a decrease in water quality [25-27].

The 2030 Agenda for Sustainable Development, adopted by all United Nations member states in 2015, provides a shared blueprint for peace and prosperity for people and the planet, now and into the future, and urges all countries to address 17 sustainable development goals (SDG), the 6th being to "ensure availability and sustainable management of water and sanitation for all" [28]. In order to reach sustainability, it is required that current tendencies are reversed, with radical changes in water policy and the implementation of innovative governance [29]. Modern management should not only consider hydrological aspects but socioeconomic constraints, having a multidisciplinary approach that should enhance:

1. Monitoring: innovative measuring of piezometric levels, drainage flows, and extractions, which should be done with regard to stakeholders in order to achieve their acceptability [30].

2. Local management of basins: reinforcing multi-institutional and multistakeholder coordination [31].

3. Decision making: providing water managers with decision support systems based on readily available indexes [27], thematic cartography [32], incorporating stakeholder responses [33].

4. Water politics: in wide areas where resources are shared between regions under different administrations, especially when there are different countries involved, conflict may arise $[34,35]$. Common management criteria, agreed in treaties, with govern- 
ment agencies partnering with stakeholders, would prevent "hydroschizophrenia" as described by Llamas [36,37].

In Alicante, many water budgets were calculated in the framework of the Basin Hydrologic Plans [38] before 2000 and the European Union (EU) Water Framework Directive (WFD). These budgets were not always based on specific data for each system but on regional extrapolations that did not consider the particular conditions of each aquifer, resulting in estimates with high uncertainty due to imprecisions in several areas such as aquifer geometry definition or recharge. The latter is one of the main hydrogeological problems; it is a complex function of many factors like topography, geology, soil, and vegetation. Hence, specific studies regarding local data are required to obtain recharge estimates and water budgets that are precise enough to advise water management.

During the last few years, recharge estimation has experienced important advances, with an increase in methodologies, computer codes, and data availability that aim to reduce the uncertainty of this variable $[39,40]$. For each case, one or several estimation methods should be chosen with regard to objectives, spatial and temporal scales, available data, type of aquifer, and climate. In many areas with water resource scarcity, accurate recharge estimates are a basic requirement for sustainable water management.

This paper presents an example of assessment of recharge for the Province of Alicante (Spain), one of the most arid regions in Europe, with high demographic pressure, that allows us to establish accurate mean water balances for the aquifers and to quantify overexploitation as a step to developing sustainable water management policies. Two hundred aquifers of different nature and dimensions have been studied with different methodologies to obtain updated mean annual recharge estimates and water budgets.

The result is a comprehensive set of figures (with water balances for each aquifer in the region) that has been presented to and accepted by the Provincial Water Board, a forum that includes water managers, deputies of the political parties represented in the province, associations of users (including farmers), chambers of commerce, and academic experts. Thus, they constitute a common ground for management and decision-making and are accepted both by stakeholders and water managers, this being the first step to integrated governance.

\section{Description of the Studied Area}

\subsection{Geographical Setting}

Alicante Province is located in southeast Spain between N latitude $37^{\circ} 2^{\prime}$ and $38^{\circ} 54^{\prime}$ and longitude $0^{\circ} 16^{\prime}$ and $1^{\circ} 5^{\prime}$ (Figure 1). It has a surface of $5817 \mathrm{~km}^{2}$, that is, $1.2 \%$ of the total national territory. It is bordered in the west by the Mediterranean Sea. From a hydrologic and administrative point of view, it is part of both the Júcar and Segura River Basins and its hydrographic demarcations.

Regarding demography, it is the fourth most populated province in the country, with $1,838,800$ inhabitants and a population density of $320 / \mathrm{km}^{2}$ [41]. Thus, water resources suffer considerable demographic stress, especially in the coastal areas that are more intensely populated. Additionally, its evolution, with a fast increase in the decade of 2000-2010, relative stabilization until 2013, and a slow decline until today, has affected the evolution of provincial water resources.

Alicante is characterized by a variety of orographic accidents, tightly linked to the geological events from Oligocene, when the convergence between the African and Euroasiatic plates during de Alpine orogeny created the Betic mountain range [42-45]. In this geological frame, controlled by compressive forces in the northwest-southeast direction, there is a series of calcareous reliefs, highly abrupt, with west-southwest and east-northeast axes; in between, the valleys are usually covered with marls. On the coast, influenced by the evolution of the Mediterranean, there are detrital sedimentary basins that are particularly extensive in the south of the province.

To aggregate and present the results of this paper, nine sectors or regions are defined, coincident with the districts of the province, an administrative division of historical origin, 
linked to elements of physiography and hydrology shared by the municipalities that integrate them. These districts, which have served as a frame to characterize provincial water resources [46,47], have been tagged as the following sectors from north to south and east to west (Figure 1): Sector I-Marina Alta; Sector II—Marina Baja; Sector III—L'Alcoiá; Sector IV—El Comtat; Sector V—L'Alacantí; Sector VI—Alto Vinalopó; Sector VII—Medio Vinalopó; Sector VIII—Bajo Vinalopó, and Sector IX—Vega Baja del Segura.

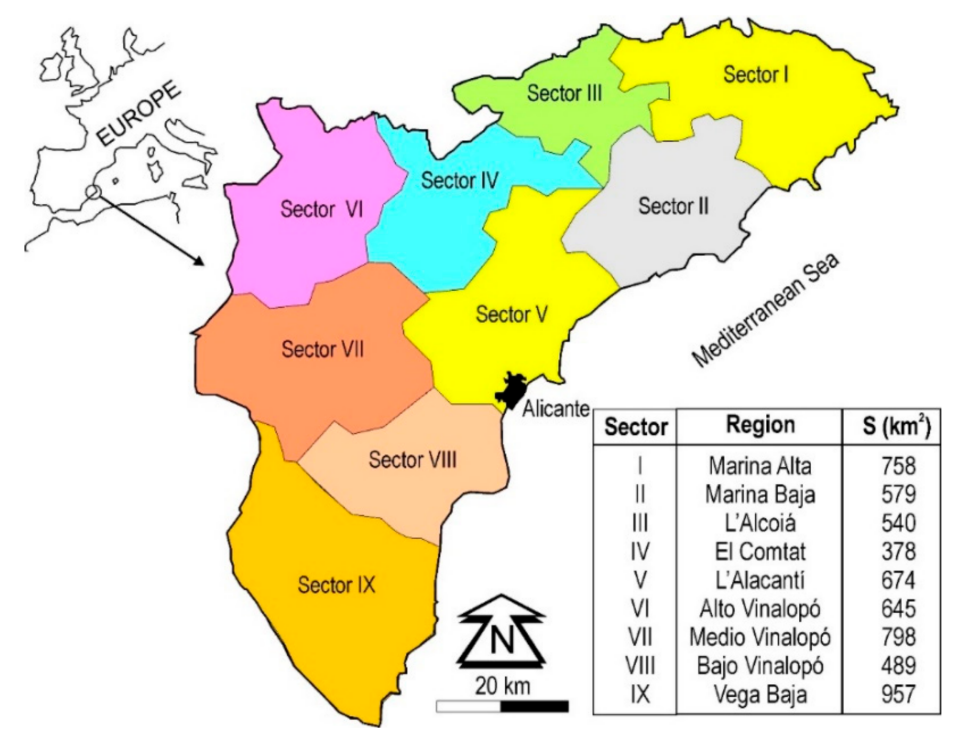

Figure 1. Map of Alicante, with the sectors used in this paper and their surfaces (S) in $\mathrm{km}^{2}$, coincident with traditional administrative regions.

\subsection{Climatic Setting}

Generally speaking, the province of Alicante is in a typical Mediterranean climatic area, with mild winters and marked summer drought [48-50]. It has domains that range between semiarid and semihumid conditions. The humid temperate regimen is located in the northern areas. On the other hand, the southern areas have a semiarid climate, leeward of the NE winds. In both northern and central-southern areas, rainfall usually happens in very strong events, generally in autumn and winter, causing significant floods [51-55].

Topography plays a key role in pluviometry distribution. Provincial ranges intercept streams of air loaded with humidity, provoking rainfall. Due to the effect of mountain landscapes, there is a double precipitation gradient, with maximum values in the northeast, decreasing towards the south and west, and, at the same time, in the coastal areas, there is always less rainfall than in the inland areas at the same latitude [56].

To irregular spatial distribution, the seasonality of rainfall and the fact that intense rainfall events are frequent are added. These events are usually related to autumn convective situations, associated with the formation of warm, very humid, and unstable air masses as a consequence of the high temperature of the waters of the Mediterranean Sea after the summer. This phenomenon is amplified by the presence of isolated depression at high levels (DANA, is the acronym in Spanish) that is responsible for events of high magnitude [57,58].

All these factors produce mean annual rainfalls of about $1000 \mathrm{~mm}$ in the northeast (Sectors I, II, III), which decrease in the southwest towards Sectors V (L'Alacantí), VI, VII, VIII (Vinalopó), and IX (Vega Baja), where means hardly reach $350 \mathrm{~mm} /$ year (Figure 2a). Seasonal distribution of rainfall is determined by a maximum in autumn (the humid season accumulates between $40 \%$ and $50 \%$ of total annual rainfall) that follows the minimum of summer (of about $10 \%$ of annual rainfall). 

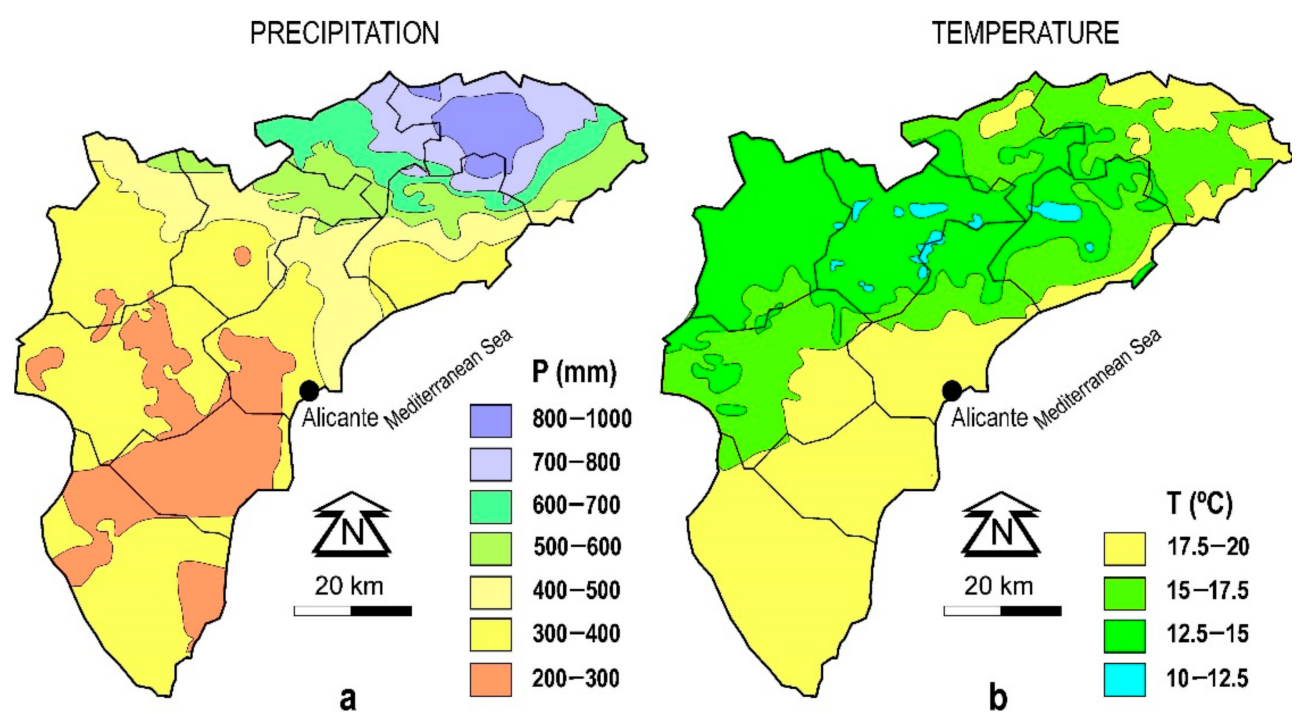

Figure 2. Spatial distribution of (a) mean annual $\mathrm{p}(\mathrm{P})$ in $\mathrm{mm}$ and $(\mathbf{b})$ temperatures $(\mathrm{T})$ in ${ }^{\circ} \mathrm{C}$ in the province of Alicante from 1971 to 2000. Modified from the Climatic Atlas viewer [56]: http: / / agroclimap.aemet.es (accessed on 15 October 2021).

Temperature distribution is also conditioned by height, distance to the sea, and latitude. Along the shoreline, temperatures are warm, while the inland climate is more continental. Lower temperatures are registered inland (Sectors I, III, and IV), with mean annual values under $15^{\circ} \mathrm{C}$. On the coast, with mean annual values of about $18{ }^{\circ} \mathrm{C}$, winters show daily mean values of $11^{\circ} \mathrm{C}$. Temperatures do not usually drop under $0^{\circ} \mathrm{C}$ on the coast, while inland, the mean daily measures for winter are relatively low, ranging between 4 and $6{ }^{\circ} \mathrm{C}$. Maximum values, with an annual mean of $18.5^{\circ} \mathrm{C}$, appear in the towns of the south and decrease slowly towards the north, reaching $17.5^{\circ} \mathrm{C}$ in Sector I (Marina Alta; Figure 2b).

Reference evapotranspiration (ETo) values are high, ranging between 900 and $1300 \mathrm{~mm} /$ year [56]. Higher values are concentrated in the areas of lower rainfall. This results in higher atmospheric evaporative demands than inputs of precipitation, something typical of semiarid regions but quite exceptional for the rest of Europe.

\subsection{Hydrogeology Setting}

The hydrogeology of Alicante is strongly linked to geological structures. The presence of different geological domains that constitute the Betic range [44], together with complex tectonics, breaks the spatial continuity of geological formations (Figure 3). The result is strong compartmentation of permeable rock substrate and a high number of differentiated aquifers. This study uses the latter definition of aquifers from the Water Information System of Diputación de Alicante (DPA, Alicante Provincial Council), with a total of 200 aquifers which with water budgets have been updated, an increased number compared with previous studies $[12,46]$. 


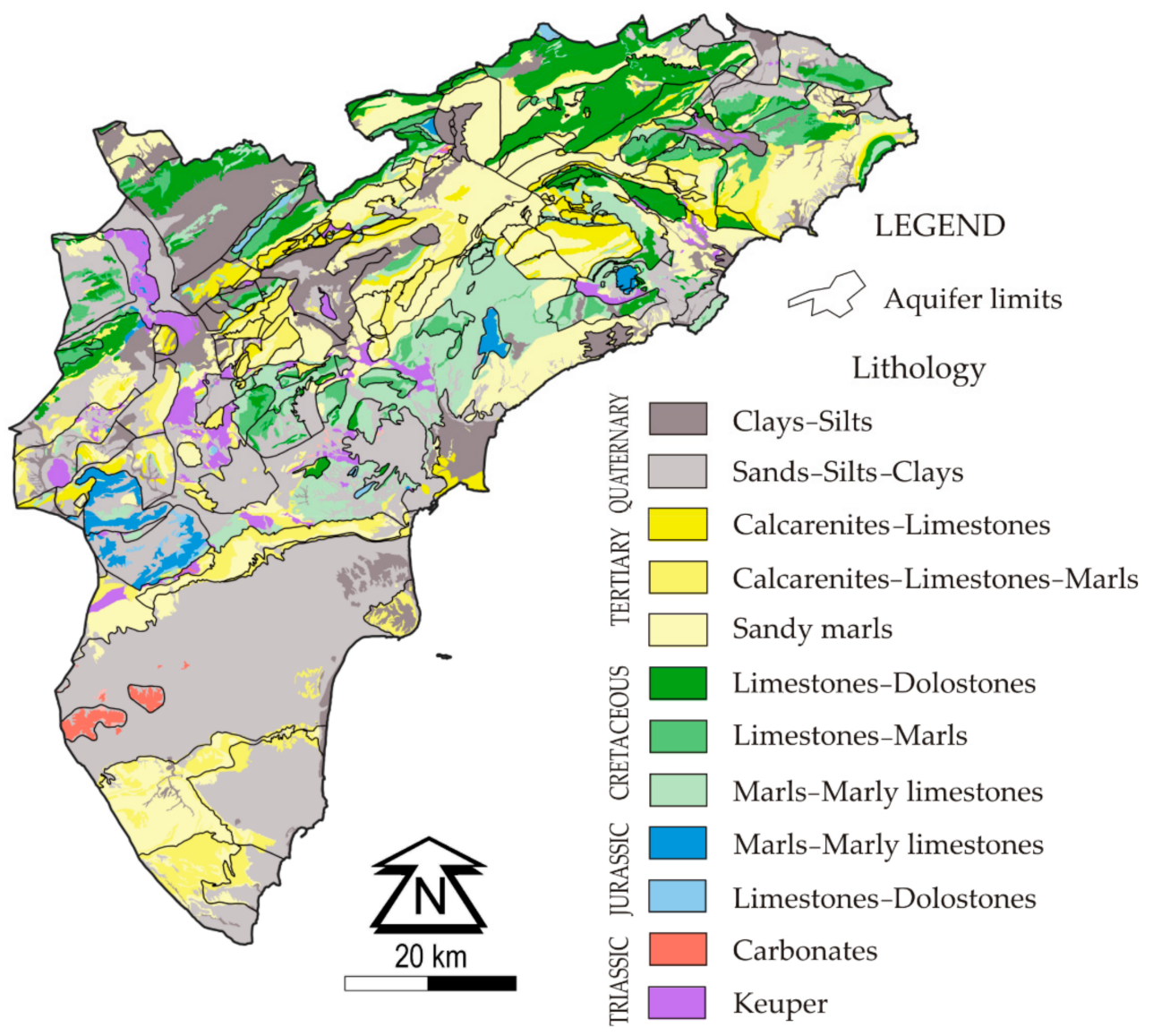

Figure 3. Map of main geological formations in the Alicante province.

The northern part of the province shows more continuous geological formations and an abundance of permeable rocks. Some aquifers in Sectors I, II, III, and IV are quite wide and, so, have important storage capacities. Most of the aquifers are carbonated. There are mainly Cretaceous limestones and dolomites, but also Tertiary calcarenites and sandstones (Figure 3).

On the other hand, in the southern areas, there is a greater presence of marly and loamy formations and higher structural complexity, which determines smaller aquifers, many with poor hydraulic parameters. Together with the carbonate Cretaceous and Jurassic aquifers, there are detrital aquifers, which are smaller and have worse hydraulic characteristics. Therefore, these southern regions have a concentration of overexploitation problems, mainly in Sectors VI (Alto Vinalopó) and VII (Medio Vinalopó) [11,46].

Finally, it should be highlighted that the quality of provincial groundwaters for current uses, urban supply, and agriculture is good [12,46,47,58] in many areas of Sectors I, II, III, and IV. The abundant carbonate aquifers offer water of low mineralization and facies types calcium bicarbonate or calcium-magnesium bicarbonate. This good quality has the exceptions of coastal aquifers (with marine intrusion) and aquifers of meridional areas (Sectors VI, VII, and VIII; with higher values of mineralization due to the presence of bodies of Triassic evaporitic rocks) [59].

\section{Data and Methods}

\subsection{Data}

Recharge estimation and water balances for the provincial aquifers are based on data from the Water Information System (WIS) of Diputación de Alicante (DPA, Alicante Provincial Council). This system has evolved for three decades and integrates information on virtually all provincial aquifers. Its core information is the inventory of water spots 
and monitoring networks, an extension of the original network of the Geological Survey of Spain (IGME). An important number of these monitoring points have obtained continuous remote measures. During 2020, about 450 remote stations were operative, receiving data from over 5000 sensors. Stations transmit the data via radio and mobile telephony. Remote measures are reinforced with manual gauging networks, both to check and calibrate remote measured data and to record the data of points that are still not monitored automatically.

In this study, the data used have been mainly from piezometric, spring flow, exploitation, and meteorological data networks:

(a) Piezometric network: 345 points, measuring 159 aquifers; 190 points are manual measured, and 155 points have continuous monitoring.

(b) Spring flow gauging stations: 65 points, of which 30 are automated with continuous level probes or flowmeters that allow the evaluation of drainage of about 30 aquifers.

(d) Exploitation network: 711 pumping wells in 111 aquifers, 48 with remote flowmeters.

(e) Meteorologic network: data of the National Meteorologic Agency (AEMET), completed with 20 automated data points from DPA.

Additionally, DPA WIS includes recharge and flow models (both results and files of the models themselves) for a number of provincial aquifers that have been developed in the last 15 years; these have been essential for this study.

\subsection{Methods}

The objective of this study is the assessment of annual mean recharge and the update of water budgets for the provincial aquifers. These results summarize and homogenize the results of a number of studies accomplished by DPA—using readily applicable methods without the requirements of unavailable or difficult-to-obtain data - throughout the past three decades [60-73]. Results are validated, to a certain extent, by the evolution of water table levels and are presented as maps and tables, showing the relationships between absolute recharge values and recharge rates and aquifers type and climate. These estimates serve as a guide to provincial water management, as they are consistent and comparable for the different aquifers.

The diversity of the aquifers themselves implies that recharge estimation cannot be accomplished using a single methodology. For each case, with regard to availability of data, spatial and temporal scales, aquifer type, or climatic features, the most appropriate method was chosen (Figure 4). The methodologies used have been soil water budget models, groundwater flow models, spring flows analysis, the water-table fluctuation method, comparison of infiltration coefficients between similar aquifers, and combinations of the former.

The soil water balance model has been widely used to evaluate recharge from precipitation, usually combined with GIS techniques [61,62] and flow models [63]. The code used was RENATA ("REcarga NATural de Acuíferos", translated Natural Aquifer Recharge), which was developed in Alicante (Spain) by DPA and IGME [74] and used on some small karst aquifers with good results [75]. Due to its simplicity and the low number of parameters that this methodology needs, it will be used by the Spanish administration to estimate the recharge of aquifers in the next Water Planning cycle, at least for aquifers shared between different major basins. The greatest advantage of this code is that it allows us to simulate recharge using some variations of the classic Thornthwaite model coupled with a Curve Number model, which combines simplicity and reduced data requirements with refinements of the classic model [74,76]. All the options are available in a GIS environment of discretized and distributed parameters and input data, both in space and time. RENATA inputs include climatic data, soil parameters, and even the possibility of introducing irrigation, if necessary. Daily precipitation and maximum, minimum, and daily average air temperature are the basic input data required, while the parameters that model soil are maximum available soil water content and curve number. Input data are introduced as time series in the case of climatic data and series used for calibration, such as observed water table levels and spring drainages, or as cartographic layers, in the case 
of climatic sectors, soil characteristics, or irrigation data. Soil parameters, which play an essential role in recharge estimations, have been calibrated in the model using the reference of values obtained from previous works on the aquifers or the outflows of the aquifers.

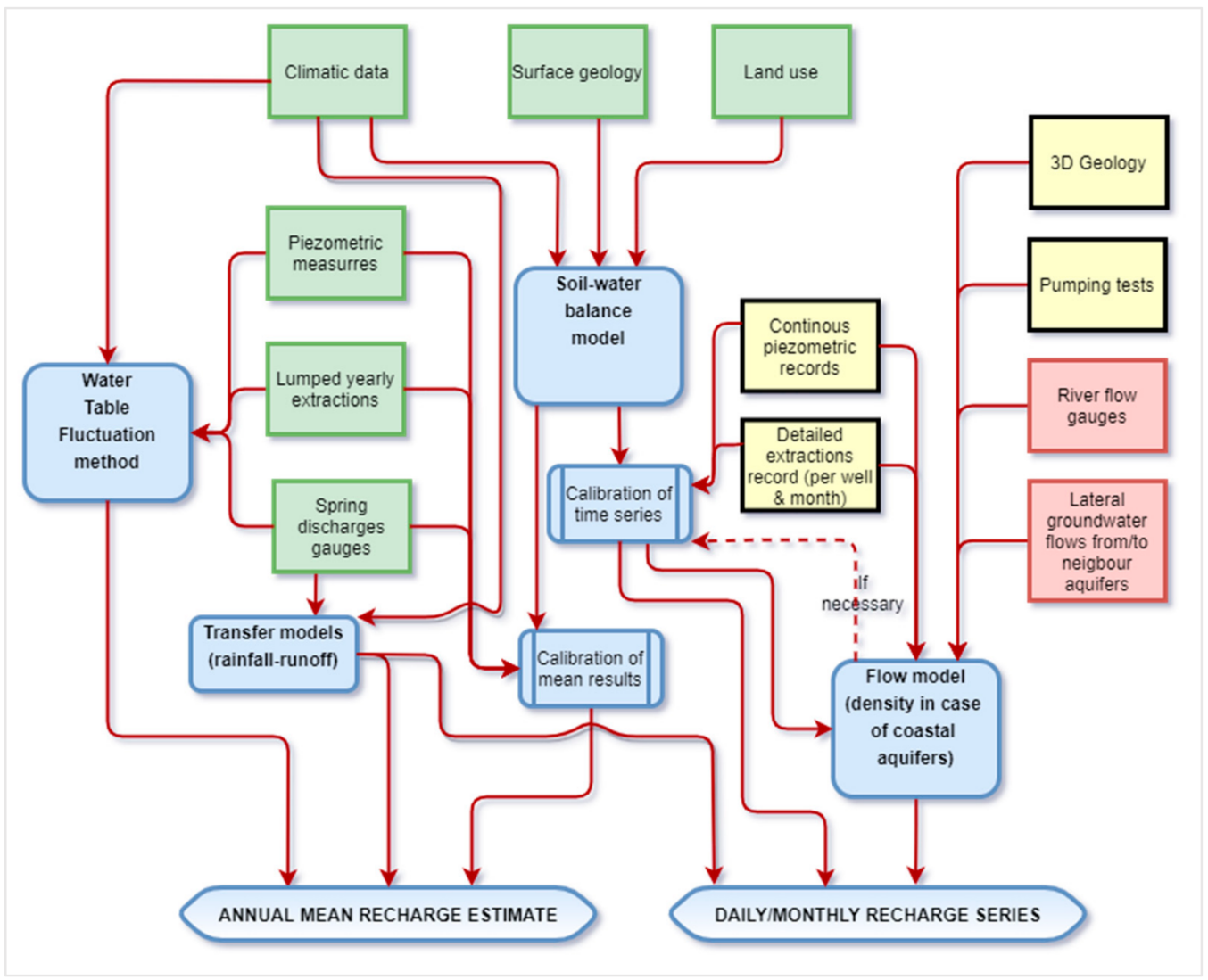

Figure 4. The diagram shows the inputs required for each of the recharge estimation methods applied. Rectangles indicate input data, and their color, the availability for the area: always available (green); sometimes or partially available (yellow); difficult or unavailable (red). Depending on these inputs, different methods are chosen and results delivered.

Potential evapotranspiration ( $E T P$ or $E T_{0}$ ) can be computed from temperature data by any of the methods available in RENATA software (Thornthwaite, Hargreaves, Penman, or Blaney-Criddle). Actual evapotranspiration and effective rainfall are computed using potential evapotranspiration and rainfall data, either with the Thornthwaite balance method [76] or with the improvement by G. Girard [74] (Figure 5), applying for each time period $I$, the following expression:

$$
P_{i}=E T R_{i}+L L U_{i}+\Delta R_{i}
$$

where $P_{i}$ is rainfall $(\mathrm{mm})$, and $\Delta R_{i}$ is the increment of soil water storage usable by plants $(\mathrm{mm})$. 


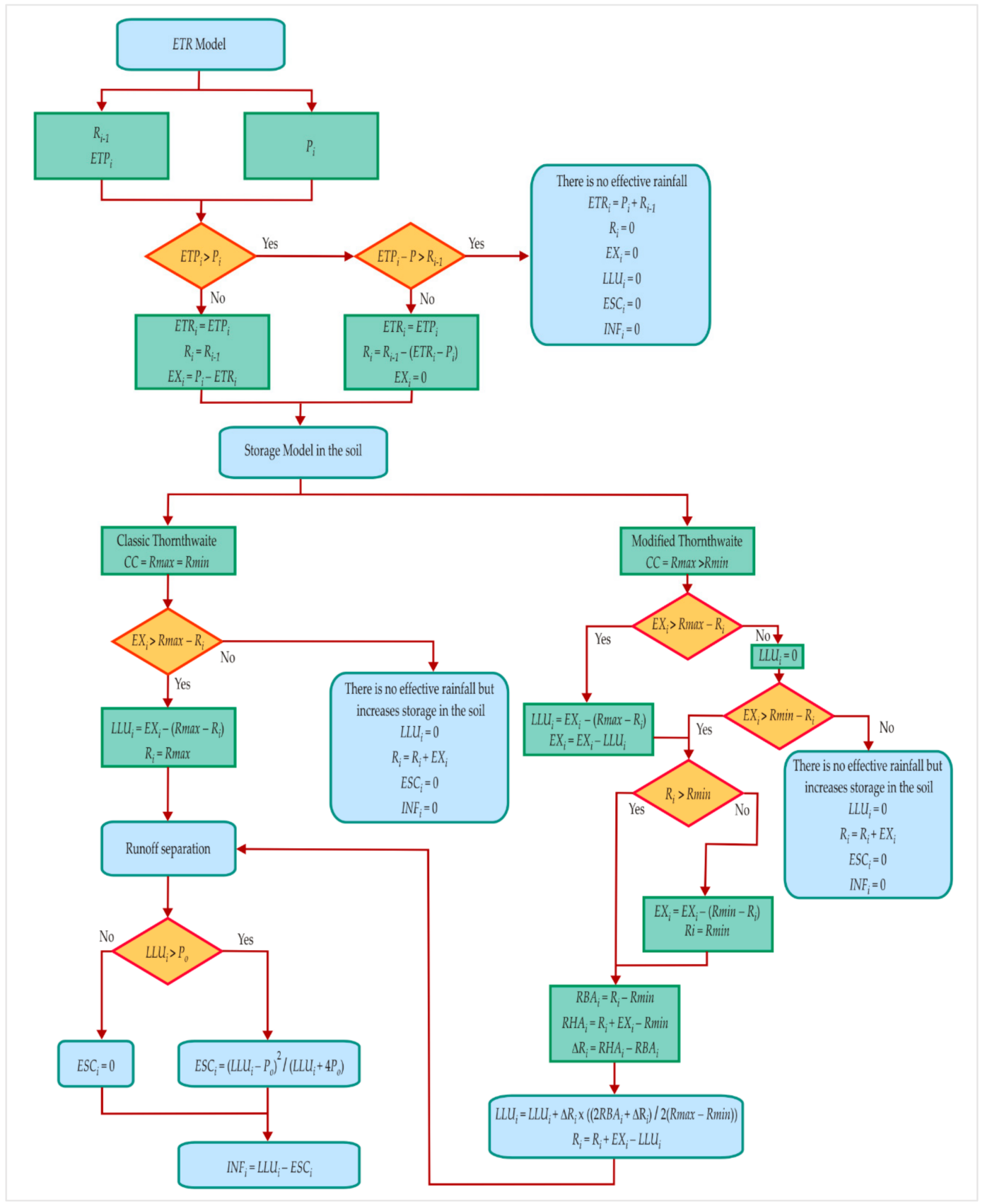

Figure 5. Algorithm for soil water balance, implemented in Natural Aquifer Recharge (RENATA) software.

This formula makes the following assumptions:

$$
E T R_{i} \leq E T P_{i}
$$

- $\quad$ The soil is able to store only a certain volume of water called field capacity (CC), which depends mainly on rock type and soil depth.

- Subject to the availability of rainfall and soil water, the first priority is to meet the needs of $E T R_{i}$, up to its limit $\left(E T P_{i}\right)$, and then increase soil water storage up to its maximum (CC).

- $\quad$ The excess water, after $E T P_{i}$ and CC demands are met, integrates $L L U_{i}$.

The variant introduced by Girard [74] considers that excess rainfall is stored in two soil reservoirs (Figure 6). If the volume of water stored in the previous period $\left(R_{i-1}\right)$ is less than a certain value $R \min$, then the excess rainfall $\left(E X_{i}=P_{i}-E T R_{i}\right)$ is completely 
stored (reservoir one). If $R_{i-1}$ is between $R$ min and a maximum value Rmax (equal to field capacity $C C$ ), $E X_{i}$ is divided into a portion to increase soil water storage (of reservoir two) and another portion that is added to superficial runoff:

$$
L L U_{i}=\max \left(R_{i-1}+P_{i}-R \max , 0\right)+\Delta R_{i} \cdot\left(2 R B A_{i}+\Delta R_{i} \cdot\right) /(2 \cdot(R \max -R \min ))
$$

where

$$
\begin{gathered}
R B A_{i}=\max \left(R \min , R_{i-1}\right)-R \min \\
R H A_{i}=\min \left(\left(R_{i-1}+P_{i}\right), R \max \right)-R \min \\
\Delta R_{i}=\max \left(0,\left(R H A_{i}-R B A_{i}\right)\right) \\
R_{i}=\Delta R_{i}+E X_{i}-L L U_{i}
\end{gathered}
$$

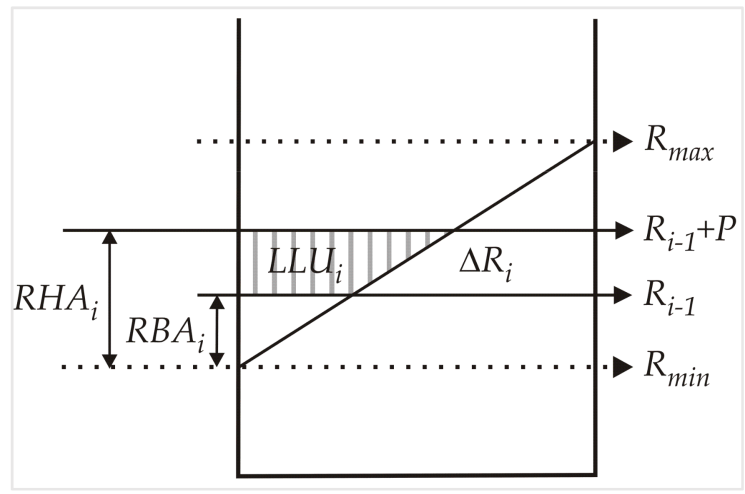

Figure 6. Conceptual model of soil for the Girard method [74].

Infiltration $\left(I N F_{i}\right)$ and surface runoff $\left(E S C_{i}\right)$ are computed by decomposing effective rainfall according to the curve number methodology of the USA Soil Conservation Service, using the Témez approach [77].

Map algebra between the previous layers (climate, soil, and irrigation) results in an "intersection layer". Each intersection represents a group of cells with the same input and parameter data. The outputs of the model are obtained for both the full aquifer extent and each intersection. Outputs include actual evapotranspiration, infiltration, and runoff and irrigation drainage to the aquifer.

Recharge estimates in the most extensive and complex aquifers, of which there is usually enough information on water table levels, spring output, and pumped volumes, have been accomplished by means of mathematical flow models. In many cases, the recharge series obtained from the soil water budget was used as input to the flow model, facilitating the calibration of the flow model and, at the same time, testing the suitability of the estimated recharge series.

The models MODFLOW (the United States of America Geological Survey Modular Ground-water Model) [78] and SEAWAT (the United States of America Geological Survey Program for Simulation of Three-Dimensional Variable-Density Ground-Water Flow and Transport) [79] have been used for coastal aquifers. These well-known models, developed by the USGS, are widely used in hydrogeology to foresee the behavior of the aquifer in terms of potential and flows. However, they can be used indirectly to estimate recharge when accurate information about water table levels and aquifer outputs is available. The process is based on the calibration of recharge values with the model until it reproduces correct piezometric-observed changes. There have been multiple studies that have used this methodology to estimate recharge in several hydrogeologic contexts, both directly [80] or coupled with other models [81-83].

For those aquifers without enough geometric information or data to build distributed soil water budgets or flow models, but with some water table level measurements and 
exploitation data, different versions of the water-table fluctuation method (WTF), a simple method that has been widely used to estimate recharge [84-86], have been used. This method is based on the premise that water table level increases are due only to the input of recharge, which causes an increase in water storage in the aquifer. This is, in fact, a way to formulate the continuity equation $I-Q=\Delta S$, where $I$ represents the inputs that are equal to recharge plus lateral subterranean inflows, $Q$ are the outputs (due to pumping and natural discharges) and $\Delta S$ storage variations, all referring to a time interval. Ultimately, it is about establishing a balance of inputs, outputs, and storage variation, based on the available data. The application of the method has presented particularities in each aquifer, depending on the different availability of information.

The analysis of discharge by springs has been the methodology used in karst aquifers whose springs are controlled. The use of transfer models (rainfall-ground flow) based on the operation of two modules or reservoirs (one for the unsaturated zone and the other for the saturated zone) allows us to obtain a function to simulate flows from the input of rain.

Finally, the application of the different methodologies described has allowed the determination of infiltration coefficients for most aquifers, which have been extrapolated to complement the WTF method for the aquifers for which little information is available.

\section{Results}

As stated before, recharge estimates are the result of different studies and different methodologies, homogenized by the use of data from the same networks and a common approach to defining concepts and methodologies. The most trustworthy results probably come from coupling a recharge model with a groundwater model, calibrated with piezometric evolutions, as all the elements of balance have to be taken into account and are consistent among them.

Figure 7 shows a typical example of the kind of fitting achieved in these models [60], after considering, as in the case of the Orba aquifer, climatic and river flow data, extractions, piezometric levels, and the remaining available hydrogeological data (e.g., geometry, parameters). These good results result in consistency between the conceptual model and the balance components.

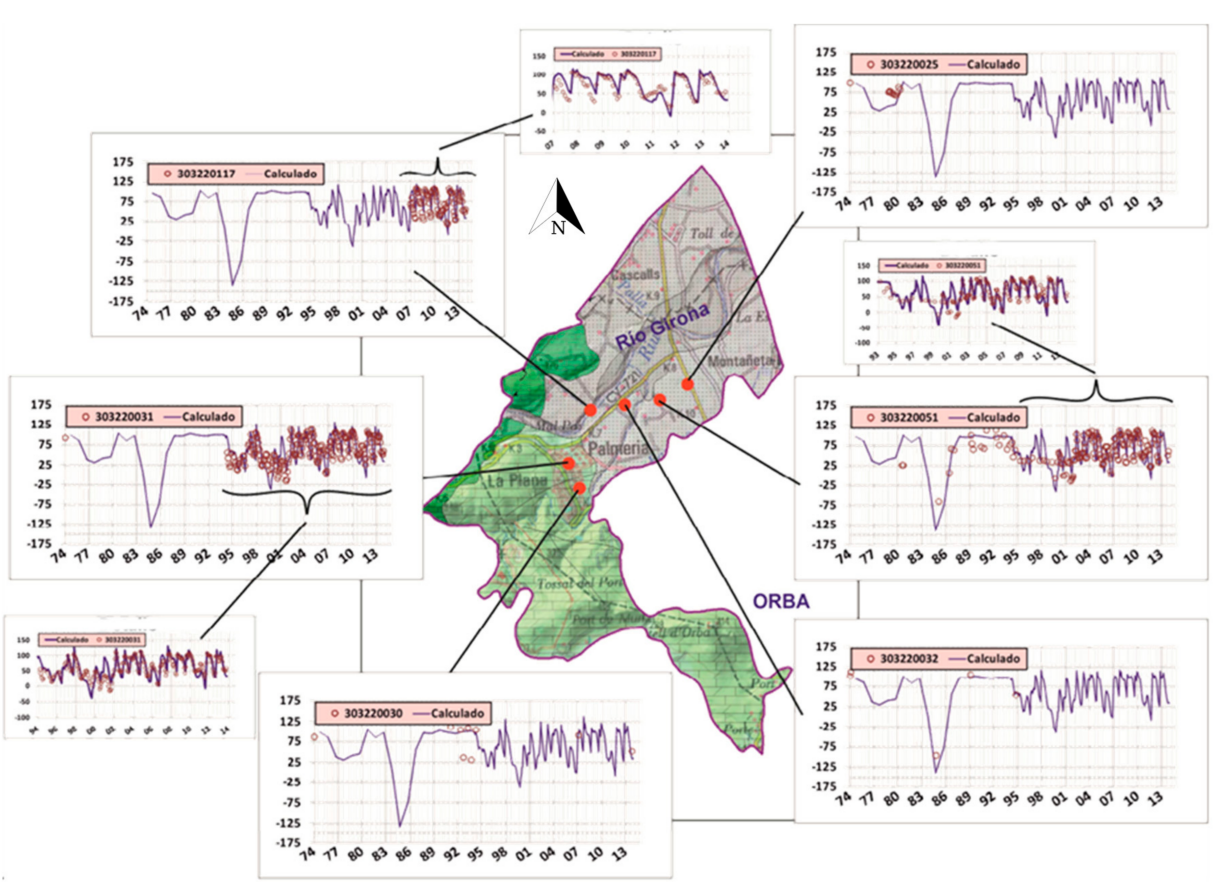

Figure 7. Simulated levels (continuous line) vs. observed levels (red dots) for some wells of the Orba aquifer in Alicante. From [60]. 
In those cases where there is not enough data, and more simplified methods such as the water transfer fluctuation or the transfer models are used, good correlations are also found [60,69] between simulated and measured (Figure 8) data; however, the possibilities of misrepresenting some balance components are higher.

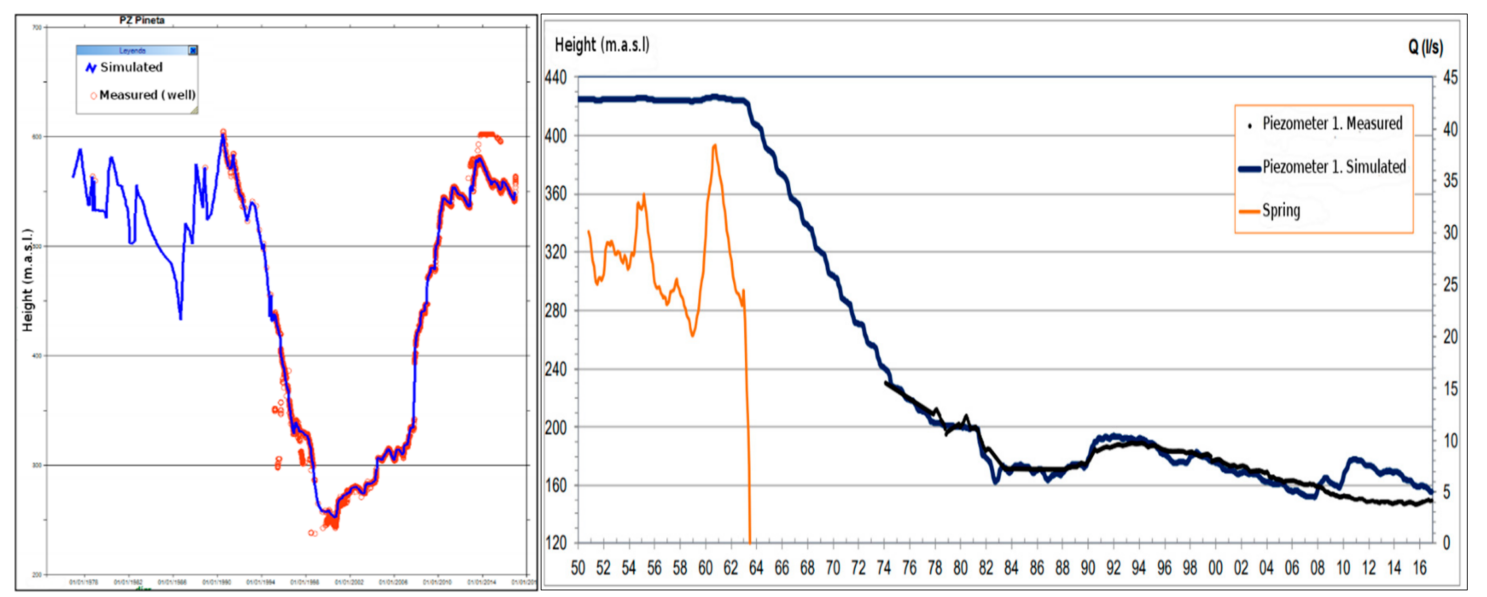

Figure 8. Simulated levels (continuous line) vs. observed levels (red dots) for some wells of the Orba aquifer in Alicante. From [60].

Recharge could be defined, in general terms, as the process of input of water into an aquifer from outside the contour that limits it, reaching the saturated zone and becoming part of groundwater storage $[87,88]$. Recharge from precipitation, intermittent flow in riverbeds, excess in irrigation, and leaks in urban areas have been considered in the models of previous studies that substantiate the water balances presented in this paper $[12,47,59,60,64-73,75]$. For semi(-arid) zone recharge, especially in mountainous areas such as the province of Alicante, infiltration from precipitation is usually the main cause of water entry into the aquifers; since it occurs over vast areas of land, even a low precipitation recharge rate can still provide large volumes of water. In the case of Alicante, the results show that direct recharge from precipitation accounts for more than $70 \%$ of the total recharge of aquifers.

As is foreseeable, infiltration has shown a strong correlation with the exposure of permeable rocks and soils on the surface. Broadly speaking, the surface of permeable outcrops occupies a total of $3600 \mathrm{~km}^{2}, 61.2 \%$ of the provincial surface, from which $1228 \mathrm{~km}^{2}$ show high or very high permeability, $652 \mathrm{~km}^{2}$ have medium permeability, and $1720 \mathrm{~km}^{2}$ have low permeability. The remaining surface area $\left(2280 \mathrm{~km}^{2}\right)$, up to $5880 \mathrm{~km}^{2}$ of total provincial surface, is occupied by practically impermeable materials (Figure 4).

The more significant permeability areas are mainly related to reliefs constituted by Cretaceous and Tertiary carbonate rocks in Sectors I, III, and VI (Marina Alta, El Comtat, and Alto Vinalopó). Other carbonate massifs, located in other sectors of the province, also show areas of high permeability. On the contrary, areas with lower permeability are related to outcrops of Tertiary marly rocks, extensively present in the northern part of the province, and Triassic Keuper facies. Additionally, different detrital formations in the south show low permeability values, reflecting rather poor hydraulic characteristics.

It should be stated that the permeability values that have been used are qualitative and derived from the lithology of the substrate, as mapped in geological cartography, rather than values obtained from infiltration tests in the field. This approach was used after considering the availability of data, the correlation that exists between bedrock and the soil it develops, and the low level of thickness that soils have in this region, especially over permeable rocks that outcrop mountainous areas. Comparing Figure 9 versus Figures 10 and 11, a good correlation between this qualitative permeability mapping and the recharge mapping is observed. 


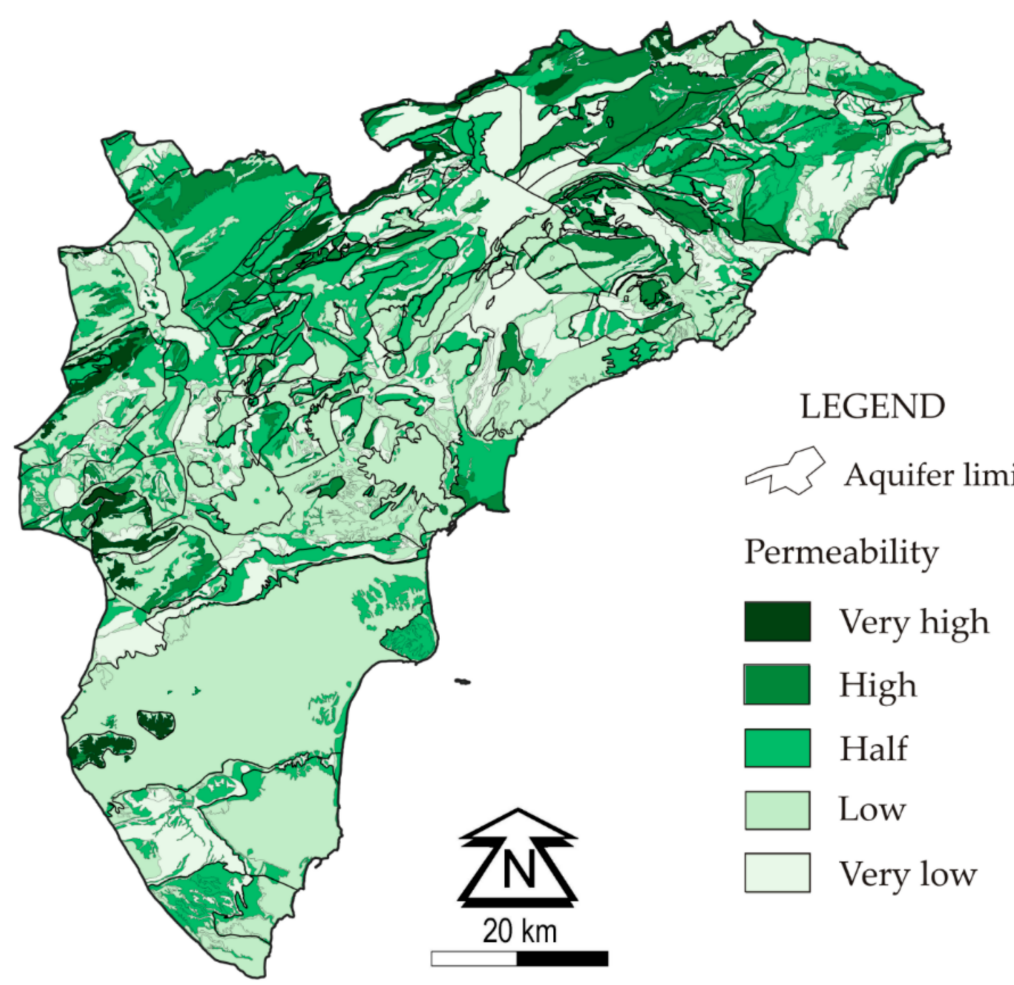

Figure 9. Permeability of the substrate in the Alicante province.

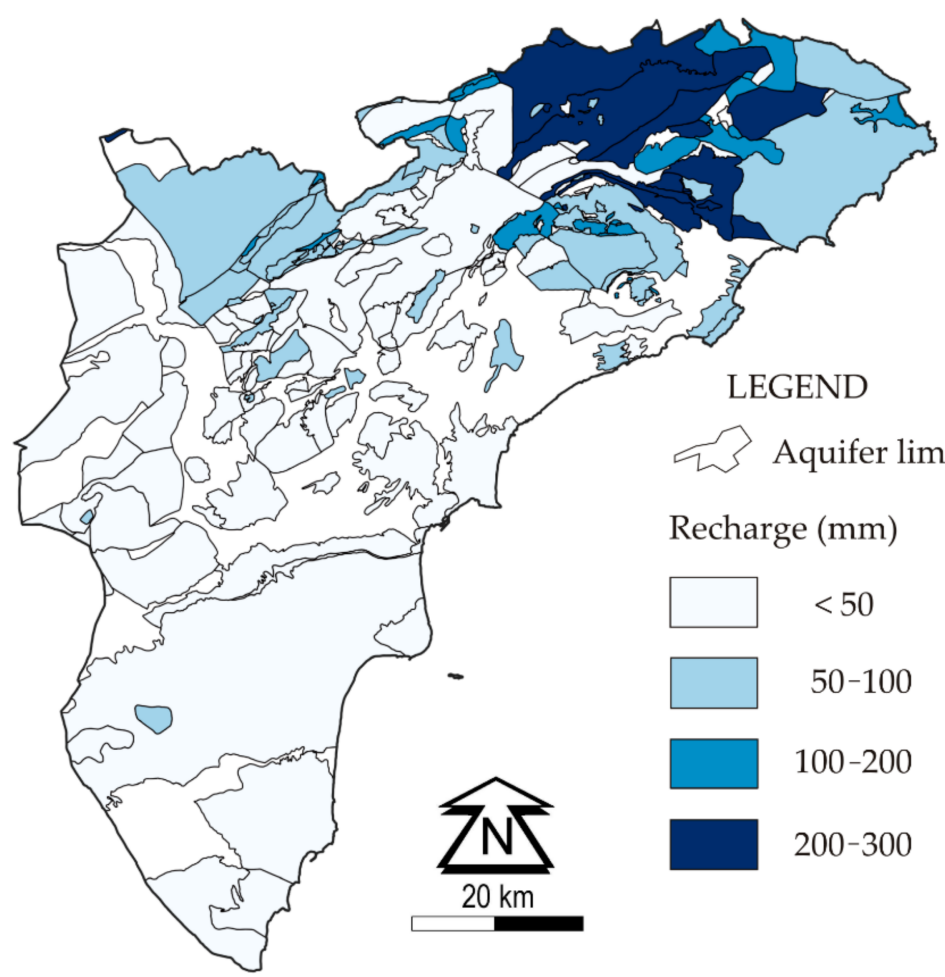

Figure 10. Distribution of annual mean recharge from precipitation for the aquifers of Alicante. 


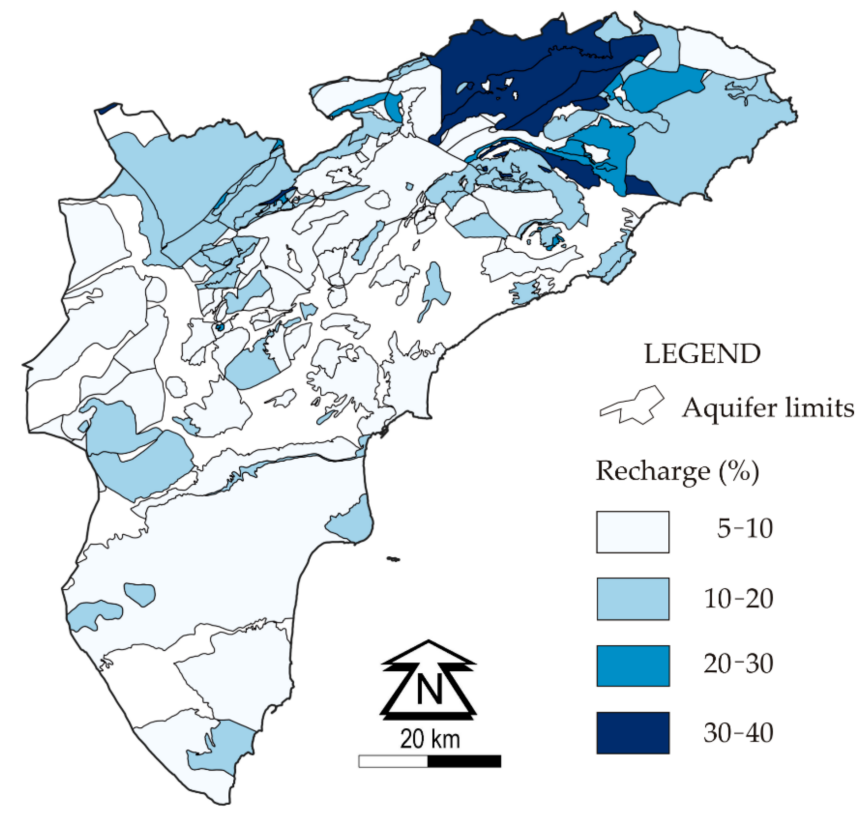

Figure 11. Distribution of recharge rates for aquifers of Alicante.

The application of different methodologies to the 200 provincial aquifers has allowed us to establish the different magnitudes of the balance. Special attention has been paid to recharge from precipitation over the outcrops of the aquifers due to both its quantitative relevance and the fact that it can be extrapolated and compared with other regions (Table S1). Recharge values range between 10 and $300 \mathrm{~mm} /$ year. Most of the provincial aquifers (94) show mean recharge values of under $50 \mathrm{~mm} /$ year (Figure 12), while 55 aquifers have values between 50 and $100 \mathrm{~mm}$. This means that approximately $75 \%$ of the aquifers in the area are recharged by less than $100 \mathrm{~mm}$ per year. Only 20 aquifers have inputs over $200 \mathrm{~mm} /$ year, that is, approximately $5 \%$ of the aquifers of the province.

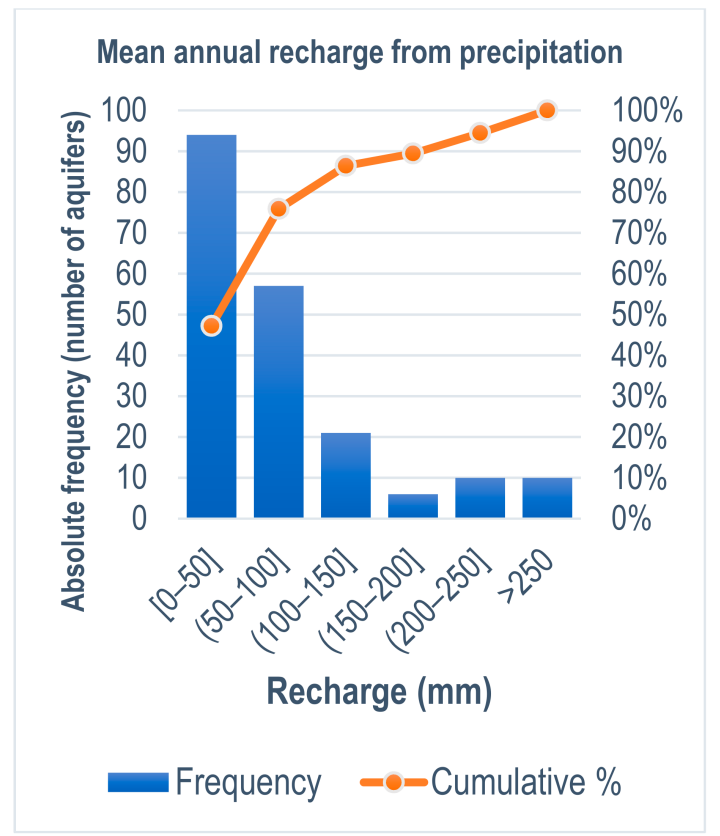

(a)

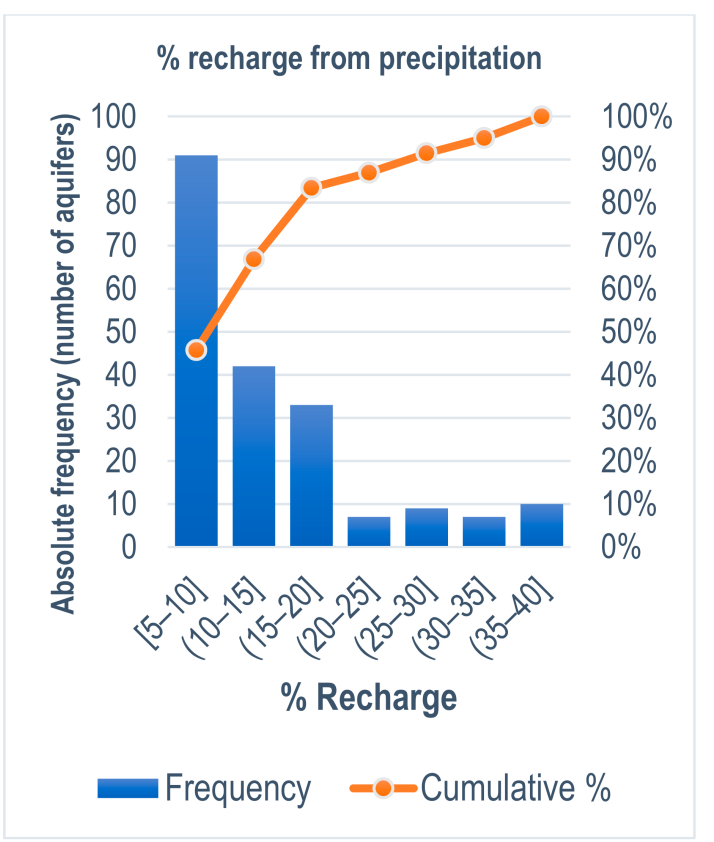

(b)

Figure 12. Histograms for the studied aquifers of (a) mean annual recharge from precipitation (mm) and (b) recharge from precipitation coefficients (\%). 
Regarding the spatial distribution of recharge from precipitation in the province of Alicante, the highest values, between 200 and $300 \mathrm{~mm} /$ year, are reached on some carbonate outcrops from the Cretaceous period in the mountains of Sector I (Marina Alta), east of Sector IV (El Comtat), and north of Sector II (Marina Baja) (Figure 10). These sectors also have a concentration of most of the recharge areas with between 50 and $200 \mathrm{~mm} /$ year from precipitation. The rest of the province, with more than two-thirds of the provincial surface, presents recharge values from precipitation of under $50 \mathrm{~mm} /$ year.

The provincial average rate of recharge from precipitation is $12 \%$ of total precipitation, which represents an average recharge of $69 \mathrm{~mm}$ /year (Table 1). The sector in which the highest recharge rate occurs, $24 \%$, is Sector I (Marina Alta), that is, $189 \mathrm{~mm} /$ year, which is a value well above the rest. However, there are several aquifers where the recharge coefficients range between $30 \%$ and $40 \%$ (Figure 11). The humid character of this region, with provincial rainfall maximums, together with a predominance of carbonate aquifers with strongly karstified outcrops, explains the high recharge rates.

Table 1. Weighted averages of recharge from precipitation expressed as mean annual millimeters $(\mathrm{mm})$ and recharge rates (in \%) for different sectors in the province of Alicante.

\begin{tabular}{cccc}
\hline Sector & $\begin{array}{c}\text { Mean Recharge } \\
(\mathbf{m m})\end{array}$ & Recharge Rate (\%) & Number or Aquifers \\
\hline I Marina Alta & 189 & 24 & 25 \\
\hline II Marina Baja & 90 & 14 & 36 \\
\hline III L'Alcoià & 62 & 12 & 25 \\
\hline IV El Comtat & 56 & 9 & 32 \\
\hline V L'Alacantí & 27 & 6 & 25 \\
\hline VI Alto Vinalopó & 47 & 10 & 18 \\
\hline VII Medio Vinalopó & 30 & 9 & 30 \\
\hline VIII Bajo Vinalopó & 22 & 7 & 6 \\
\hline IX Vega Baja & 27 & 9 & 200 \\
\hline Total & 69 & 12 & \\
\hline
\end{tabular}

Sectors II (Marina Baja), III (L'Alcoiá), IV (El Comtat), and VI (Alto Vinalopó) have average rates ranging between $9 \%$ and $15 \%$, with average recharges between 47 to $90 \mathrm{~mm} /$ year. Meanwhile, the rest of the sectors show recharge rates between $6 \%$ and $10 \%$ and average values of $33 \mathrm{~mm}$ /year.

However, throughout the province, regardless of their climatic location, there are aquifers with recharge rates between $10 \%$ and $40 \%$ of total precipitation, which are preferentially related to aquifers of a carbonate nature; percentages below $10 \%$ are associated with detrital and Tertiary aquifers of medium and low permeability.

Finally, Table 2 synthesizes the results of water budgets for all provincial aquifers (aggregated for the different sectors). It specifies the different annual average input and output volumes for all the aquifers of each sector. Among the inputs are recharge from precipitation (RP) and recharge from intermittent flow in riverbeds (IF). In addition, there are returns (RT) from irrigation and urban networks, namely, volumes of irrigation water that are not used by the plants and have reached the aquifer, and, to a lesser extent, leaks in distribution and sanitation networks. The estimation of the latter is still uncertain, although they are relatively low volumes compared to total recharge. Finally, and for balance purposes, the table includes as inputs the groundwater flows between adjacent connected aquifers (GF). 
Table 2. Water balances for the aquifers of different sectors of Alicante in $\mathrm{hm}^{3} /$ year.

\begin{tabular}{|c|c|c|c|c|c|c|c|c|c|}
\hline \multirow{3}{*}{ SECTOR } & \multicolumn{5}{|c|}{ INFLOWS } & \multicolumn{3}{|c|}{ OUTFLOWS } & \multirow{3}{*}{ Balance } \\
\hline & \multicolumn{3}{|c|}{ Recharge } & \multirow{2}{*}{$\mathrm{GF}^{4}$} & \multirow{2}{*}{ Total } & \multirow{2}{*}{$\mathbf{P}^{5}$} & \multirow{2}{*}{$\mathrm{NO}^{6}$} & \multirow{2}{*}{ Total } & \\
\hline & $\mathbf{R P}^{1}$ & $\mathrm{IF}^{2}$ & $\mathrm{RT}^{3}$ & & & & & & \\
\hline I Marina Alta & 170.3 & 10.0 & 18.2 & 24.1 & 222.6 & 56.3 & 166.3 & 222.6 & 0 \\
\hline II Marina Baja & 38.5 & 0.4 & 2.4 & 3.8 & 45.0 & 18.6 & 26.5 & 45.0 & 0 \\
\hline III L'Alcoià & 27.8 & 0 & 0 & 1.0 & 28.8 & 14.1 & 15.3 & 29.4 & -0.6 \\
\hline IV El Comtat & 12.0 & 0.2 & 0 & 3.9 & 16.1 & 7.0 & 10.5 & 17.5 & -1.4 \\
\hline V L'Alacantí & 7.6 & 0.2 & 4.7 & 0.3 & 12.8 & 5.7 & 7.0 & 12.8 & 0 \\
\hline VI Alto Vinalopó & 30.8 & 4 & 3.9 & 0.6 & 39.2 & 56.1 & 2.0 & 58.1 & -18.9 \\
\hline VII Medio Vinalopó & 20.2 & 1.1 & 1.0 & 0.4 & 22.7 & 24.0 & 4.8 & 28.8 & -6.1 \\
\hline VIII Bajo Vinalopó & 2.2 & 0 & 0 & 0 & 2.2 & 0.3 & 1.9 & 2.2 & 0 \\
\hline IX Vega Baja & 29.3 & 0 & 36.1 & 12.0 & 77.4 & 17.0 & 61.6 & 78.6 & -1.2 \\
\hline
\end{tabular}

${ }^{1}$ RP: recharge from precipitation. ${ }^{2}$ IF: recharge from intermittent flow in riverbeds. ${ }^{3}$ RT: returns from irrigation and urban networks. ${ }^{4}$ GF: lateral groundwater inflows. ${ }^{5} \mathrm{P}$ : pumping. ${ }^{6} \mathrm{NO}$ : natural output.

Regarding the outlets, at present, most of the outputs from the provincial aquifers are produced by pumping wells $(\mathrm{P})$. However, there are still, albeit to a lesser extent, outflows through riverbeds and springs, which include outflows through springs, drains, wetlands, and diffuse outlets, the latter being small upwellings, without sufficient entity to locate them at a specific point. Lastly, there can be lateral flow to other aquifers or the sea. These springs, riverbeds, or subterranean outflows have been grouped under the denomination of natural outlets (NOs).

Results at the regional level show the importance of infiltration from precipitation compared to other types of recharge. The provincial average percentage is $72.6 \%$, varying between 100\% (Sectors III (L'Alcoiá) and VIII (Bajo Vinalopó)) and 37.9\% (Sector IX (Vega Baja)), largely due to the fact that most aquifer permeable outcrops are of fractured or karstified rocks that favor direct infiltration. It is also significant that there are small magnitudes associated with recharge from losses in river courses, always lower than $10 \%$ and mostly below $5 \%$, as an effect of the lack of permanent watercourses, the high permeability of mountainous areas, and the irregularity of flows that appear in fast flood events. Finally, the recharge associated with the return of irrigation or losses in urbanized areas is only important in those southern sectors of the province where agricultural areas occupy large extensions of land.

Regarding the provincial water balance, groundwater resources present a total average deficit of $28.2 \mathrm{hm}^{3}$ /year. This situation of water deficits has been highlighted for a long time [74], although all data have indicated that this deficit has been reduced considerably compared to past decades.

\section{Discussion}

From the point of view of water resource management, it is essential to assess what part of precipitation is available for regulation and use, either in rivers or as groundwater. Precise quantification of available water is even more necessary in dry Mediterranean regions with scarce resources, heavily dependent on groundwater. The province of Alicante, together with the rest of the southeast peninsular territory, is in the region with the least available water resources in the entire European Union, also surrounded by a large area with remarkably low availability of water compared to the rest of the European environment and under an uncertain future due to climate change $[19,20,31,57]$. This situation of water deficit reaches its maximum towards the south of the province and decreases progressively towards the north and linked to solar insolation and the thermal regime. 
However, the quantification of groundwater resources depends on the assessment of recharge, which is not always straightforward [75,88-90].This task is especially complex and prone to uncertainties when it comes to relatively large areas with a significant number of groundwater systems. This is the case of Alicante, where there have been 200 aquifers defined with varied characteristics and dimensions, with different hydrodynamic evolutions, and located in different climatic conditions.

Good monitoring networks for hydrodynamic and climatic variables, like the one kept by DPA and other public administrations in the province of Alicante, are essential for obtaining data and information about the behavior of recharge to the aquifers.

Furthermore, these data are key for the assessment of recharge, with different estimation methodologies. Figure 13 shows the methods applied in this study to evaluate recharge, both by the number of aquifers and by total aquifer surface. It should be noted that the method used for most of the provincial aquifers $(66 \%)$ has been the water table fluctuation method, followed by flow models (19\%) and soil water budget recharge models $(8 \%)$. In $5 \%$ of aquifers, estimation of the recharge was carried out through the combined use of a soil water budget recharge model and a flow model. The reason that the WTF method is the one most used is that it requires a reduced amount of input information and does not require continuous time series for decades. However, when Figure $13 \mathrm{~b}$ is observed, it can be seen that for most of the surface covered by aquifers in the province $(72 \%)$, either flow or recharge models, or a combination of both, have been used. The main advantage of combining several methods is that the estimated magnitude shows less uncertainty $[39,40,91]$. These figures show that the estimates of recharge for the largest aquifers and, consequently, those with greater resources are more robust compared to those for the smaller aquifers with less potentiality as water sources. Consequently, nearly three-quarters of the extension of Alicante aquifers has been modeled with flow or soil water budget models, or both, to obtain balances and recharge from precipitation. For the rest, balances were completed through the study of relationships between inputs, outputs, and storage variation (WTF method) and analysis of discharges by springs, especially in those aquifers that do not have pumping.

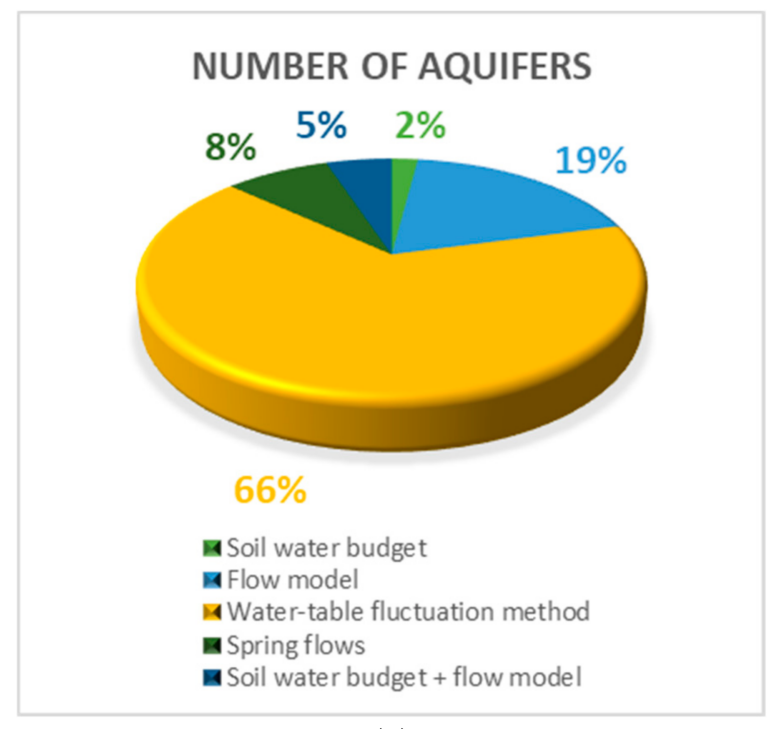

(a)

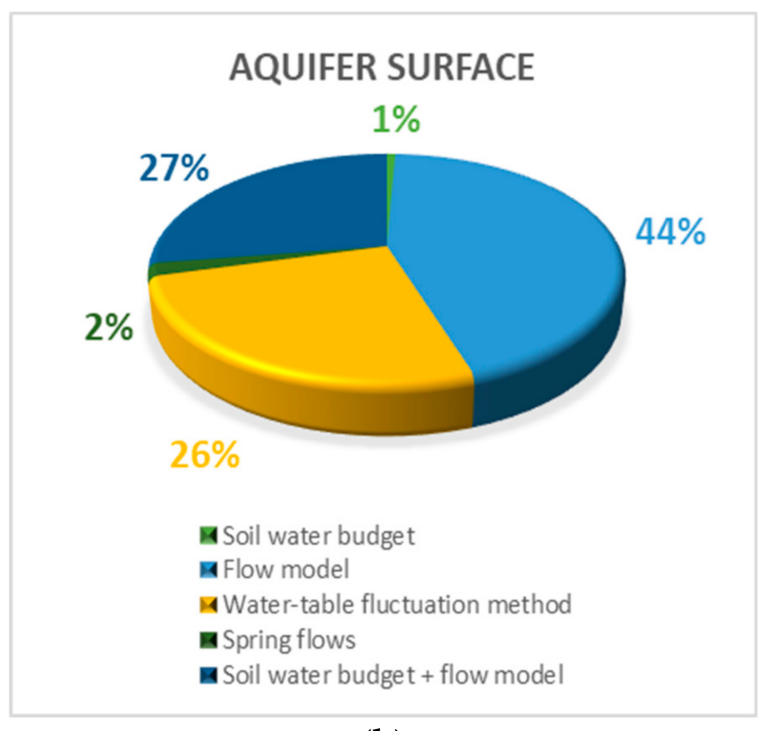

(b)

Figure 13. Methodologies used for the estimation of recharge by number of aquifers (a) and aquifer surface (b).

These results may be subject to some criticism due to the lack of efficiency coefficients to test the predictive skill of the hydrological models used. This kind of analysis, which is quite complex as it deals with a large number of aquifers and different kinds of models, exceeds the scope of this paper; nevertheless, it points the way for future research. 
Nonetheless, there are reasons to trust the results, at least the mean annual values. First, the use and comparison of the data with water table levels by Diputación de Alicante were on a continuous basis, and no important deviations were found in the general trends. In addition, there have been comparisons with alternative estimates performed with the models of the River Basin Authorities (RBAs). Although results are not directly comparable because there is no direct correlation between aquifers and the groundwater-bodies concept used by RBAs after the Water Framework Directive [92], the output values of the balance for the province differed by less than $10 \%$ [93].

The updated recharge data have been the basis for elaborating the maps shown in the previous section, which allow us to picture how values and rates change in the region and, therefore, analyze the key factors that determine recharge. Although recharge is a complex process dependent on a multitude of factors, results indicate that precipitation and lithology are the two factors that have the greatest influence on the recharge distribution pattern in the province of Alicante. Thus, as can be seen in Figures 10 and 11, it is in the northern sectors (those with the highest rainfall and occurrence of carbonate aquifers, including the larger ones) that the highest recharge rates are achieved. The value of the Pearson correlation coefficient between the mean annual precipitation values for each outcrop and its rate of recharge rate is 0.59 . Between the lithologies presented in Figure 3 and the percentage recharge rates, the value of the correlation coefficient drops to 0.16 . In other words, the rate of recharge (as a percentage) is significantly correlated with the total volume of precipitation but is also influenced by other factors that highlight the lithology/permeability of the substrate.

The number of rainy events and their magnitude (greater in the north of the province due to the pattern of provincial precipitation, where orographic effects caused by the reliefs that act as an obstacle to atmospheric circulation), together with the abundance of carbonate rocks with high permeabilities in the reliefs of this region, are responsible for the higher recharge rates. The influence of episodes of intense rain, frequent throughout the Mediterranean arc, must also be highlighted as it significantly contributes to increasing recharge in all provincial aquifers. The contribution of these intense precipitations to recharge is more significant to the percentage of recharge in the southern aquifers.

The recharge from precipitation is predominantly diffuse for practically all carbonate rock outcrops, with the exception of the northern sectors, in which the development of epikarst (somewhat higher, carbonate rocks) usually outcrop bare or with little ground cover, and there is a reduced development of exokarst morphologies. Additionally, the intense tectonic in the region is responsible for the intense fracturing of carbonate massifs, favorable to recharge, as it increases secondary permeability.

The rest of the inflows, such as infiltration from riverbeds or irrigation returns, have a more local character. The small number and entity of rivers in the region determine that there are streams flowing over permeable lands and increasing recharge only in some sectors, which is what usually happens to detrital aquifers.

Superficial flow is stational and scarce, and, thus, there is a small number of dams in the province. The storage capacity of artificial reservoirs in Alicante is only $0.56 \%$ of the total capacity in Spain [94]. The La Pedrera dam, which has $80 \%$ of the total storage capacity of the province, together with the Crevillente dam, regulates water from the Tajo-Segura transfer but do not receive natural runoff. The Amadorio [94], Beniarrés, and Guadalest reservoirs basically receive water from springs, and the latter is filled with pumped water from wells in drier periods. Therefore, the impact of these dams on recharge is negligible. In the north of the province, the Isbert dam, built on the permeable outcrop of the Mediodía aquifer, increases recharge that naturally occurs from the riverbed [72], something included in the balance for Sector I (Table 2).

In Sectors IX and III, where intensive agriculture is present, there are significant irrigation returns to detrital aquifers.

The physical and climatic characteristics of the province of Alicante determine a low average recharge rate $(12 \%)$ from total rainfall. This value is typical of semiarid areas and 
is within the range of values found for some aquifers in this and other regions with similar characteristics [91,95-98]. This explains why the entries in many of the provincial systems have been unable to balance the intensive extractions that have taken place for decades, especially in Sectors IV, VI, and VII. The final result is that the province of Alicante presents a balance deficit, and almost all sectors present problems related to overexploitation.

\section{Conclusions}

Alicante Province has experienced important economic development due to its transformation from rainfed to irrigated agriculture, as well as to an increase in tourism and industry. Groundwater has been a basic resource of water supply for these activities.

Regarding hydrogeological features in the province, most of the aquifers are carbonated, mainly Cretaceous limestones and dolomites. There are also some detrital aquifers; however, not only is their extension small, but they also have worse hydraulic characteristics and, in some cases, poor quality water. Broadly speaking, the northeast and southwest areas of the province are two differentiated domains. The first one has larger carbonated aquifer systems under more humid climatic conditions, with average annual rainfall ranging between 500 and $900 \mathrm{~mm}$. Thus, aquifers have significant recharge rates and greater resources. On the other hand, in the southwest, where the carbonate aquifers are smaller due to high tectonic compartmentalization, with annual rainfall averages ranging between 250 and $400 \mathrm{~mm}$, recharge rates are low and resources are scarce. Therefore, the main overexploitation problems are concentrated in these areas, specifically in the basin of the river Vinalopó.

Accurate aquifer balances and, especially, good recharge estimates are required for water management. This study updates the water balances of 200 aquifers defined in Alicante, accomplished by a combination of methodologies, where soil water and groundwater flow models stand out if there are enough data available. Though these balances appear to fit well into the general trends of aquifer level evolution, further research has to be done to assess the accuracy of the predictive models to avoid misrepresentation of some balance components.

The primary source of recharge $(72.6 \%$ of the total) is direct infiltration from rainfall. The results show a strong correlation between the values of this direct recharge from precipitation and total average rainfall and, to a lesser extent, lithologies. The average recharge rate for the aquifers of Alicante is $12 \%$, ranging between maximum values of almost $40 \%$ in the northeast to values of $5-6 \%$ in the southwest. Therefore, if recharge rates have to be estimated from limited small sets of data in similar areas, the amount of precipitation and its structure are the most important factors to account for. The absolute average recharge amount for Alicante is $69 \mathrm{~mm}$, with maximums of about $300 \mathrm{~mm}$ and minimums of $10 \mathrm{~mm}$.

Total provincial input is currently estimated to be about $445 \mathrm{hm}^{3} /$ year, with a difference between inputs and outputs of $28.2 \mathrm{hm}^{3}$ /year on average. This means that the moderate-to-small recharge rates are incapable of balancing the intensive extractions that have taken place for decades.

Availability of precise and updated recharge estimates for the whole province is of crucial importance for water managers to design policies and strategies to achieve sustainability. However, management should consider not only hydrology but also socioeconomic constraints and multi-institutional and multistakeholder interactions or conflicts. Discussion towards consensus requires common data that are easily understood by all the stakeholders. Readily available aquifer budgets and recharge maps for a whole region, presented homogeneously by institutions such as Diputación de Alicante and the University, may constitute this common ground for water governance.

Supplementary Materials: The following are available online at https:/ / www.mdpi.com/2073-444 1/13/6/862/s1, Table S1: Recharge rates and mm.

Author Contributions: Conceptualization, J.M.A. and E.G.-S.; methodology M.F.-M. and R.P.; formal analysis, J.M.A. and M.F.-M.; writing—original draft preparation, J.M.A., E.G.-S., M.F.-M., and R.P.; 
writing - review and editing, J.M.A. and M.F.-M. All authors have read and agreed to the published version of the manuscript.

Funding: This research was funded partially by the projects of the Spanish Ministry of Economy and Competitiveness (ALTERACLIM; CGL2015-69773-C2-1-P) and the Ministry of Science and Innovation (PID2019-111332RB-C21). In the same way, this work was partially funded by Cátedra del Agua (Water Chair) of the University of Alicante and Diputación de Alicante (https: / catedradelaguaua. org/ accessed on 10 February 2021).

Institutional Review Board Statement: Not applicable.

Informed Consent Statement: Not applicable.

Data Availability Statement: The data presented in this study are available in the article and as Supplementary Material.

Acknowledgments: The authors would like to acknowledge the support and encouragement of Joaquín Melgarejo Moreno for this paper and Patricia Fernández Aracil for the assistance with its submission. In addition, they thank the staff of the Water Department (Área de Ciclo Hídrico) of Diputación de Alicante for the continuous feedback offered.

Conflicts of Interest: The authors declare no conflict of interest. The funders had no role in the design of the study; in the collection, analyses, or interpretation of data; in the writing of the manuscript, or in the decision to publish the results.

\section{References}

1. Wada, Y.; Beek, L.; Bierkens, M.F. Nonsustainable groundwater sustaining irrigation: A global assessment. Water Resour. Res. 2012, 48. [CrossRef]

2. Wada, Y.; Wisser, D.; Bierkens, M.F. Global modeling of withdrawal, allocation and consumptive use of surface water and groundwater resources. Earth Syst. Dynam. 2014, 5, 15-40. [CrossRef]

3. Siebert, S.; Burke, J.; Faures, J.M.; Frenken, K.; Hoogeveen, J.; Döll, P.; Portmann, F.T. Groundwater use for irrigation-A global inventory. Hydrol. Earth Syst. Sci. 2010, 14, 1863-1880. [CrossRef]

4. Ibañez, J.; Valderrama, J.M.; Puigdefábregas, J. Assessing overexploitation in Mediterranean aquifers using system stability condition analysis. Ecol. Model. 2008, 218, 260-266. [CrossRef]

5. Werner, A.D.; Zhang, Q.; Xue, L.; Smerdon, B.D.; Li, X.; Zhu, X.; Yu, L.; Li, L. An initial inventory and indexation of groundwater mega-depletion cases. Water Resour. Manag. 2013, 27, 507-533. [CrossRef]

6. Famiglietti, J.S. The global groundwater crisis. Nat. Clim. Chang. 2014, 4, 945-948. [CrossRef]

7. Llamas, M.R.; Custodio, E.; de la Hera, A.; Fornés, J.M. Groundwater in Spain: Increasing role, evolution, present and future. Environ. Earth Sci. 2015, 73, 2567-2578. [CrossRef]

8. Rupérez-Moreno, C.; Senent-Aparicio, J.; Martínez-Vicente, D.; García-Aróstegui, J.L.; Calvo-Rubio, F.C.; Pérez-Sánchez, J. Sustainability of irrigated agriculture with overexploited aquifers: The case of Segura basin (SE, Spain). Agric. Water Manag. 2017, 182, 67-76. [CrossRef]

9. Sahuquillo, A. La explotación intensa de los acuíferos en la cuenca baja del Segura y en la cuenca del Vinalopó. Ing. Agua 2016, 20, 13-27. [CrossRef]

10. Rodríguez-Estrella, T. The problems of overexploitation of aquifers in semi-arid areas: Characteristics and proposals for mitigation. Bol. Geol. Min. 2014, 125, 91-109.

11. Custodio, E.; Andreu-Rodes, J.M.; Aragón, R.; Estrela, T.; Ferrer, J.; García-Aróstegui, J.L.; Manzano, M.; Rodríguez-Hernández, L.; Sahuquillo, A.; del Villar, A. Groundwater intensive use and mining in south-eastern peninsular Spain: Hydrogeological, economic and social aspects. Sci. Total Environ. 2016, 559, 302-316. [CrossRef] [PubMed]

12. DPA-IGME (Ed.) Atlas Hidrogeológico de la Provincia de Alicante; Diputación Provincial de Alicante: Alicante, Spain, $2015 ;$ p. 282. ISBN 978-84-7840-959-4.

13. Zarzo, D.; Prats, D. Desalination and energy consumption. What can we expect in the near future? Desalination 2018, 427, 1-9. [CrossRef]

14. Jódar-Abellan, A.; López-Ortiz, M.I.; Melgarejo-Moreno, J. Tratamiento de aguas residuales y reutilización de aguas en España. Situación actual y perspectivas. Water 2019, 11, 1551. [CrossRef]

15. Prats-Rico, D.; Jódar-Abellán, A. No convencionales: Análisis de la reutilización de aguas residuales el agua en la provincia de Alicante. In El Agua en la Provincia de Alicante; Melgarejo-Moreno, J., Fernández Mejuto, M., Eds.; Diputacion Provincial de Alicante-University of Alicante: Alicante, Spain, 2020; pp. 105-129. ISBN 978-84-15327-92-9.

16. Melgarejo, J. Provincia de Alicante y déficit Hídrico. In El Agua en la Provincia de Alicante; Melgarejo-Moreno, J., Fernández Mejuto, M., Eds.; Diputacion Provincial de Alicante-University of Alicante: Alicante, Spain, 2020; pp. 9-13. ISBN 978-84-15327-92-9.

17. Milly, P.C.; Dunne, K.A.; Vecchia, A.V. Global pattern of trends in streamflow and water availability in a changing climate. Nature 2005, 438, 347-350. [CrossRef] [PubMed] 
18. Van der Linden, P.; Mitchell, J.E. (Eds.) ENSEMBLES. In Climate Change and its Impacts: Summary of Research and Results from the ENSEMBLES Project; European Environmental Agency: Exeter, UK, 2009; p. 160.

19. Ferrer, J.; Pérez-Martín, M.A.; Jiménez, S.; Estrela, T.; Andreu, J. GIS-based models for water quantity and quality assessment in the Júcar River Basin, Spain, including climate change effects. Sci. Total Environ. 2012, 440, 42-59. [CrossRef]

20. IPCC. Climate Change 2014: Synthesis Report. Contribution of Working Groups I, II and III to the Fifth Assessment Report of the Intergovernmental Panel on Climate Change; Pachauri, R.K., Meyer, L.A., Eds.; IPCC: Geneva, Switzerland, $2014 ;$ p. 151.

21. Jyrkama, M.I.; Sykes, J.F. The impact of climate change on spatially varying groundwater recharge in the Grand River watershed (Ontario). J. Hydrol. 2007, 338, 237-250. [CrossRef]

22. Moutahir, H.; Bellot, P.; Monjo, R.; Bellot, J.; Garcia, M.; Touhami, I. Likely effects of climate change on groundwater availability in a Mediterranean region of Southeastern Spain. Hydrol. Process. 2017, 31, 161-176. [CrossRef]

23. Pulido-Velázquez, D.; García-Aróstegui, J.L.; Molina, J.L.; Pulido-Velázquez, M. Assessment of future groundwater recharge in semi-arid regions under climate change scenarios (Serral-Salinas aquifer, SE Spain). Could increased rainfall variability increase the recharge rate? Hydrol. Process. 2015, 29, 828-844. [CrossRef]

24. Giordano, M.; Villholth, K. (Eds.) The Agricultural Groundwater Revolution: Opportunities and Threats to Development; CABI Publishing: Wallingford, UK, 2007; Volume 3, p. 419. ISBN 978-1-84593-172-8.

25. Al-Senafy, M.; Abraham, J. Vulnerability of groundwater resources from agricultural activities in southern Kuwait. Water Manag. 2004, 64, 1-15. [CrossRef]

26. Gleeson, T.; Vander Steen, J.; Sophocleous, M.A.; Taniguchi, M.; Alley, W.M.; Allen, D.M.; Zhou, Y. Groundwater sustainability strategies. Nat. Geosci. 2010, 3, 378-379. [CrossRef]

27. Van Camp, M.; Radfar, M.; Walraevens, K. Assessment of groundwater storage depletion by overexploitation using simple indicators in an irrigated closed aquifer basin in Iran. Water Manag. 2010, 97, 1876-1886. [CrossRef]

28. United Nations. 17 Sustainable Development Goals (SDG). Goal 6: Ensure Availability and Sustainable Management of Water and Sanitation for All. United Nations Website. Available online: https://sdgs.un.org/\#goal_section (accessed on 10 February 2021).

29. Holtz, G.; Pahl-Wostl, C. An agent-based model of groundwater over-exploitation in the Upper Guadiana, Spain. Reg. Environ. Chang. 2011, 12, 95-121. [CrossRef]

30. Giordano, R.; Milella, P.; Portoghese, I.; Vurro, M.; Apollonio, C.; D’Agostino, D.; Lamaddalena, N.; Scardigno, A.; Piccinni, A.F. An Innovative Monitoring System for Sustainable Management of Groundwater Resources: Objectives, Stakeholder Acceptability and Implementation Strategy. In Proceedings of the EESMS 2010 Workshop on Environmental Energy, and Structural Monitoring Systems, Taranto, Italy, 9 September 2010; ISBN 978-142446275-9.

31. Iglesias, A.; Garrote, L.; Flores, F.; Moneo, M. Challenges to manage the risk of water scarcity and climate change in the Mediterranean. Water Resour. Manag. 2007, 21, 775-788. [CrossRef]

32. Voudouris, K.; Polemio, M.; Kazakis, N.; Sifaleras, A. An agricultural decision support system for optimal land use regarding groundwater vulnerability. J. Inf. Syst. Soc. Chang. 2010, 1, 66-79. [CrossRef]

33. Portoghese, I.; D'Agostino, D.; Giordano, R.; Scardigno, A.; Apollonio, C.; Vurro, M. An integrated modelling tool to evaluate the acceptability of irrigation constraint measures for groundwater protection. Environ. Modell. Softw. 2013, 46, 90-103. [CrossRef]

34. Hussein, H.; Menga, F.; Greco, F. Monitoring transboundary water cooperation in SDG 6.5. 2: How a critical hydropolitics approach can spot inequitable outcomes. Sustainability 2018, 10, 3640. [CrossRef]

35. Hussein, H. Yarmouk, Jordan, and Disi basins: Examining the impact of the discourse of water scarcity in Jordan on transboundary water governance. Mediterr. Politics 2019, 24, 269-289. [CrossRef]

36. Llamas, M.R.; Martínez-Santos, P. Intensive groundwater use: Silent revolution and potential source of social conflicts. J. Water Resour. Plann. Manag. 2005, 131, 337-341. [CrossRef]

37. Jarvis, T.; Giordano, M.; Puri, S.; Matsumoto, K.; Wolf, A. International borders, ground water flow, and hydroschizophrenia. Groundwater 2005, 43, 764-770. [CrossRef] [PubMed]

38. MMA. Libro Blanco del Agua; Dirección General de Obras Hidráulicas y Calidad del Agua, Ministerio del Medio Ambiente: Madrid, Spain, 2000; p. 637. ISBN 84-8320-128-3.

39. Scanlon, B.R.; Healy, R.W.; Cook, P.G. Choosing appropriate techniques for quantifying groundwater recharge. Hydrogeol. J. 2002, 1, 18-39. [CrossRef]

40. Custodio, E. Recarga de los acuíferos: Aspectos generales sobre el proceso, la evaluación y la incertidumbre (Aquifer recharge: General issues on the process, assessment and uncertainity). Bol. Geol. Min. 1998, 109, 13-29.

41. ARGOS. Portal de Información ARGOS. Generalitat Valenciana. 2018. Available online: http://argos.gva.es/va (accessed on 20 December 2020).

42. Azañón, J.M.; Galindo Zaldívar, J.; García Dueñas, V.; Jabaloy, A. Alpine Tectonics II: Betic Cordillera and Balearic Islands. In Geology of Spain; Gibbons, W., Moreno, T., Eds.; The Geological Society of London: London, UK, 2002; pp. 401-416. ISBN 1-86239-110-6.

43. Vera, J.A. (Ed.) Geología de España; SGE-IGME: Madrid, Spain, 2004; p. 890.

44. Estévez, A.; Vera, J.A.; Alfaro, P.; Andreu, J.M.; Tent-Manclús, J.E.; Yébenes, A. Alicante en la Cordillera Bética. In Geología de Alicante; University of Alicante: Alicante, Spain, 2004; pp. 39-50.

45. Sanz de Galdeano, C.; González-Castillo, L.; Galindo-Zaldívar, J.; Alfaro, P. La Cordillera Bética: Un orógeno activo. Ensen. Cienc. Tierra 2019, 27, 314-322. 
46. DPA (Ed.) Mapa del Agua de la Provincia de Alicante; Diputación Provincial de Alicante: Alicante, Spain, 2007.

47. Fernández-Mejuto, M.; Andreu, J.M.; García-Sánchez, E.; Palencia, R. Balance de recursos hídricos superficiales y subterráneos en la provincia de Alicante. Canelobre: Revista Instituto Alicantino Cultura Juan Gil-Albert 2019, 70, 70-83.

48. Font Tullot, I. (Ed.) Climatología de España y Portugal; University of Salamanca: Salamanca, Spain, $2000 ;$ p. 422.

49. Martín Vide, J.; Olcina, J. Climas y Tiempos de España; Alianza Editorial: Madrid, Spain, 2001; p. 208.

50. Olcina, J.; Moltó, E. Climas y Tiempos del País Valenciano; University of Alicante: Alicante, Spain, 2019; p. 180. ISBN 978-84-9717659-0.

51. Pérez-Cueva, A. Precipitaciones extraordinarias en la España Peninsular. Agric. Soc. 1983, 28, $189-203$.

52. Armengot-Serrano, R. Las precipitaciones extraordinarias. In Atlas Climàtic de la Comunitat Valenciana; Pérez Cueva, A., Ed.; Conselleria d'Obres Públiques, Urbanisme i Transports. Generalitat Valenciana: Valencia, Spain, 1994; Collecció Territori 4; pp. 98-99.

53. Martin-Vide, J. Spatial distribution of a daily precipitation concentration index in peninsular Spain. Int. J. Clim. 2004, 24, 959-971. [CrossRef]

54. Valdés-Abellan, J.; Pardo, M.A.; Tenza-Abril, A.J. Observed precipitation trend changes in the western Mediterranean region. Int. J. Clim. 2017, 37, 1285-1296. [CrossRef]

55. AEMET Climatic Atlas Viewer of Spain. Available online: http:/ /agroclimap.aemet.es (accessed on 15 October 2020).

56. Millán, M.M.; Estrela, M.J.; Miró, J. Rainfall Components: Variability and Spatial Distribution in a Mediterranean Area (Valencia Region). J. Clim. 2005, 18, 2682-2705. [CrossRef]

57. Tamayo-Carmona, J.; Núñez-Mora, J.A. Precipitaciones intensas en la comunidad valenciana. Análisis, sistemas de predicción y perspectivas ante el cambio climático. In Riesgo de Inundación en España: Análisis y Soluciones para la Generación de Territorios Resilientes; López-Ortiz, I., Melgarejo-Moreno, J., Eds.; University d'Alacant: Alicante, Spain, 2020; pp. 49-62. ISBN 978-84-1302-091-4.

58. Boluda, N.; Andreu, J.M.; Hernández-González, A.; Fernández, J.; Ruiz, F.; Saquete, M.D.; García, E.; Hernández-Bravo, J.A.; Rodríguez, L. La calidad de las aguas subterráneas en la provincia de Alicante: Revisión en la última década. Geotemas 2000, 1, 31-36.

59. Andreu, J.M.; Pulido-Bosch, A.; Llamas, M.R.; Bru, C.; Martínez-Santos, P.; García-Sánchez, E.; Villacampa, L. Overexploitation and water quality in the Crevillente aquifer (Alicante, SE Spain). WIT Trans. Ecol. Environ. 2008, 111, 75-84. [CrossRef]

60. Rodríguez, L.; Fernández-Mejuto, M.; Hernández Gómez, J.M.; Padilla, A. Modelos Numéricos para la Simulación de la Garantía de Suministro ante la Sequía en Acuíferos de la Marina Alta. Acuíferos de Solana de la Llosa, Orba y Maigmó; Diputación Provincial de Alicante: Alicante, Spain, 2015; p. 300.

61. Vela Mayorga, A. (Ed.) Desarrollo de un Modelo de Balance de Agua en los Suelos de Castilla-La Mancha Sobre un Sistema de Información Geográfica: Condiciones de Aplicación y Limitaciones; University of Castilla-La Mancha: Cuenca, Spain, 2001; p. 300.

62. Westenbroek, S.M.; Kelson, V.A.; Dripps, W.R.; Hunt, R.J.; Bradbury, K.R. SWM-A Modified Thornthwaite-Mather Soil-Water-Balance Code for Estimating Groundwater Recharge; US Department of the Interior, US Geological Survey, Ground Resources Program: Reston, VA, USA, 2010; p. 60.

63. Melo, D.C.D.; Wendland, E.; Guanabara, R.C. Estimate of Groundwater Recharge Based on Water Balance in The Unsaturated Soil Zone. Rev. Brasil. Ciência Solo 2015, 39, 1336-1343. [CrossRef]

64. Solís García-Barbón, L.; Rodríguez Hernández, L.; Fernández Mejuto, M. Actualización de Balances Hídricos en los Acuíferos de la Provincia de Alicante; Diputación de Alicante: Alicante, Spain, 2010; p. 75.

65. Ramos González, G.; Hornero Díaz, J.E.; Gumiel Gutiérrez, J.C.; Rodríguez Hernández, L. Implantación de Modelos de Simulación de Intrusión Marina en la Gestión de Acuíferos Costeros. Control de Evolución Temporal de Parámetros Hidrogeológicos y Balances Hídricos como Datos de Entrada al Modelo de Gestión de Acuíferos de Torrevieja y Cabo Roig; Instituto Geológico y Minero de España y Diputación de Alicante: Alicante, Spain, 2003; p. 73.

66. Padilla Benítez, A.; Gómez Fontalva, J.; Marín Carrillo, I.; Rodríguez Hernández, L.; Fernández Mejuto, M.; Hernández Bravo, J.A. Adaptación del Modelo Numérico de Simulación del Flujo en los Embalses Subterráneos de Jumilla-Villena y Vega Baja al Sistema Información Hidrogeológica Diputación de Alicante; Determinación de Reservas Útiles Dinámicas y de Suministro; Jumilla-Villena. Diputación de Alicante: Alicante, Spain, 2011; p. 136.

67. Padilla Benítez, A.; Gómez Fontalva, J.; Marín Carrillo, I.; Rodríguez Hernández, L.; Fernández Mejuto, M.; Hernández Bravo, J.A. Adaptación del Modelo Numérico de Simulación del Flujo en los Embalses Subterráneos de Quibas y Beniardà-Polop al Sistema de Información Hidrogeológica de la Diputación de Alicante; Determinación de las Reservas Útiles Dinámicas y Garantías de Suministro; Diputación de Alicante: Alicante, Spain, 2011; p. 200.

68. Marín Carrillo, I.; Padilla Benítez, A.; Rodríguez Hernández, L.; Fernández Mejuto, M.; Hernández Bravo, J.A. Adaptación del Modelo Numérico de Simulación del Flujo en el Embalse Subterráneo Solana al Sistema de Información Hidrológica de la Diputación de Alicante; Determinación de las Reservas Útiles Dinámicas y Garantías de Suministro; Diputación de Alicante: Alicante, Spain, 2010; p. 96.

69. Rodríguez Hernández, L.; Murillo Díaz, J.M. Modelo Matemático de Flujo del Acuífero de Jijona. Simulación de Alternativas de Recarga Artificial; Diputación de Alicante: Alicante, Spain, 1995; p. 99.

70. Ballesteros Navarro, B.; Rodríguez Hernández, L. Modelo de Densidad Variable en Régimen Transitorio del Acuífero Pego-Oliva; Diputación de Alicante: Alicante, Spain, 2013; p. 198. 
71. Padilla Benítez, A.; Rodríguez Hernández, L.; Fernández Mejuto, M. Migración Modelos de Simulación Numérica en Acuíferos Pinar de Camús, Cabranta, Barrancones y Crevillente a Aplicación MOFA. Implantación en SIH; Determinación Reservas útiles Dinámicas y Garantías de Suministro de Captaciones; Diputación de Alicante: Alicante, Spain, 2010; p. 186.

72. Padilla Benítez, A.; Rodríguez Hernández, L.; Fernández Mejuto, M. Servicio para Adaptación Modelos Numéricos de Simulación en Embalses Subterráneos Serral-Salinas, Mediodía y Muro de Alcoy al Sist. Inf. Hidrológica de DPA; Diputación de Alicante: Alicante, Spain, 2008; p. 154.

73. Marín Carrillo, I.; Padilla Benítez, A.; Rodríguez Hernández, L.; Fernández Mejuto, M.; Hernández Bravo, J.A. Modelo Numérico de Simulación del Flujo en el Embalse Subterráneo Almudaina-Alfaro-Segaria; Diputación de Alicante: Alicante, Spain, $2007 ;$ p. 78.

74. DPA-IGME (Ed.) RENATA: Natural Recharge to Aquifers; Diputación Provincial de Alicante: Alicante, Spain, $2012 ;$ p. 83.

75. Fernández-Mejuto, M.; Andreu, J.M.; Pla, C.; Valdés, J. Assessing groundwater recharge in two sites with different climates in the Alicante region of South-East Spain. WIT Trans. Ecol. Environ. 2019, 229, 117-127. [CrossRef]

76. Thornthwaite, C.W. An approach toward a rational classification of climate. Geogr. Rev. 1948, 38, 55-94. [CrossRef]

77. Témez, J.R. Cálculo Hidrometeorológico de Caudales Máximos en Pequeñas Cuencas Naturales; Centro de Estudios Hidrográficos (CEDEX): Madrid, Spain, 1978.

78. McDonald, M.G.; Harbaugh, A.W. A modular three-dimensional finite-difference ground-water flow model. In Open-File Report 83-875; US Geological Survey: Sandwich, MA, USA, 1984.

79. Langevin, C.D.; Shoemaker, W.B.; Guo, W. MODFLOW-2000, the U.S. Geological Survey Modular Ground-Water ModelDocumentation of the SEAWAT-2000 Version with the Variable-Density Flow Process (VDF) and the Integrated MT3DMS Transport Process (IMT). In Open-File Report 03-426; US Geological Survey: Sandwich, MA, USA, 2003; p. 43.

80. Dripp, W.R.; Hunt, R.J.; Anderson, M.P. Estimating recharge rates with analytic element models and parameter estimation. Groundwater 2006, 44, 47-55. [CrossRef] [PubMed]

81. Kim, N.W.; Chung, I.M.; Won, Y.S.; Arnold, J.G. Development and application of the integrated SWAT-MODFLOW model. J. Hydrol. 2008, 356, 1-16. [CrossRef]

82. Bailey, R.T.; Wible, T.C.; Arabi, M.; Records, R.M.; Ditty, J. Assessing regional-scale spatio-temporal patterns of groundwatersurface water interactions using a coupled SWAT-MODFLOW model. Hydrol. Process. 2016, 30, 4420-4433. [CrossRef]

83. Beegum, S.; Šimůnek, J.; Szymkiewicz, A.; Sudheer, K.P.; Nambi, I.M. Updating the Coupling Algorithm between HYDRUS and MODFLOW in the HYDRUS Package for MODFLOW. Vadose Zone J. 2018, 17, 1-8. [CrossRef]

84. Hall, D.W.; Risser, D.W. Effects of agricultural nutrient management on nitrogen fate and transport in Lancaster county Pennsylvania. J. Am. Water Resour. Assoc. 1993, 29, 55-76. [CrossRef]

85. Park, E.; Parker, J.C. A simple model for water table fluctuations in response to precipitation. J. Hydrol. 2008, 356, 344-349. [CrossRef]

86. Subramanian, T.S.; Abraham, M. Assessment of natural groundwater recharge: A case study of North Chennai Aquifer. Environ. Geosci. 2019, 26, 41-50. [CrossRef]

87. Freeze, R.A.; Cherry, J.A. Groundwater; Prentice-Hall: Englewood Cliffs, NJ, USA, 1979; p. 604.

88. Lerner, D.N.; Issar, A.S.; Simmers, I. Groundwater Recharge: A Guide to Understanding and Estimating Natural Recharge; International Contribution to Hydrogeology, 8; Verlag Heinz Heise: Hannover, Germany, 1990; p. 345. [CrossRef]

89. Wriedt, G.; Bouraoui, F. Towards a General Water Balance. Assessment of Europe; European Commission, Joint Research Centre, Institute for Environment and Sustainability: Ispra, Italy, 2009; p. 62. [CrossRef]

90. Healy, R.W. Estimating Groundwater Recharge; Cambridge University Press: Cambridge, UK, 2010. [CrossRef]

91. Touhami, I.; Andreu, J.M.; Chirino, E.; Sánchez, J.R.; Pulido-Bosch, A.; Martínez-Santos, P.; Moutahir, H.; Bellot, J. Comparative performance of soil water balance models in computing semi-arid aquifer recharge. Hydrol. Sci. J. 2014, 59, 193-203. [CrossRef]

92. European Commission. 32000L0060-EN-EUR-Lex. Directive 2000/60/EC of the European Parliament and of the Council of 23 October 2000 Establishing a Framework for Community Action in the Field of Water Policy. Available online: http: / / eur-lex.europa.eu/legal-content/EN/TXT/?uri=celex:32000L0060 (accessed on 4 March 2021).

93. Rodríguez, L.; Fernández-Mejuto, M.; Hernández, J.A.; Pérez, F.; Palencia, R.; Fernández-Rodríguez, H. Masas de agua subterránea: Acuíferos. In El Agua en la Provincia de Alicante; Melgarejo-Moreno, J., Fernández-Mejuto, M., Eds.; Diputacion Provincial de Alicante-University of Alicante: Alicante, Spain, 2020; pp. 77-104. ISBN 978-84-15327-92-9.

94. Navarro, J.; Meléndez, I.; Jordán, M.M.; Gómez, I. Masas de aguas superficiales: Embalses y lagos. In El Agua en la Provincia de Alicante; Melgarejo-Moreno, J., Fernández-Mejuto, M., Eds.; Diputacion Provincial de Alicante-University of Alicante: Alicante, Spain, 2020; pp. 49-75. ISBN 978-84-15327-92-9.

95. Scanlon, B.R.; Keese, K.E.; Flint, A.L.; Flint, L.E.; Gaye, C.B.; Edmunds, M.W.; Simmers, I. Global synthesis of groundwater recharge in semiarid and arid regions. Hydrol. Process. 2006, 20, 3335-3370. [CrossRef]

96. Aguilera, H.; Murillo, J.M. The effect of possible climate change on natural groundwater recharge based on a simple model: A study of four karstic aquifers in SE Spain. Environ. Geol. 2009, 57, 963-974. [CrossRef]

97. Andreu, J.M.; Alcalá, F.J.; Vallejos, A.; Pulido-Bosch, A. Recharge to aquifers in SE Spain: Different approaches and new challenges. J. Arid. Environ. 2011, 75, 1262-1270. [CrossRef]

98. Martos-Rosillo, S.; González-Ramón, A.; Jiménez-Gavilán, P.; Andreo, B.; Durán, J.J.; Mancera, E. Review on groundwater recharge in carbonate aquifers from SW Mediterranean (Betic Cordillera, S Spain). Environ. Earth Sci. 2015, 74, 7571-7581. [CrossRef] 